\title{
The European Bank Recovery and Resolution Directive: A market assessment
}

\author{
Livia Pancotto, ${ }^{a, *}$, Owain ap Gwilym ${ }^{b}$ and Jonathan Williams ${ }^{b}$ \\ ${ }^{a}$ Strathclyde Business School, University of Strathclyde, G4 OQU, UK \\ ${ }^{b}$ Bangor Business School, Bangor University, LL57 2DG, UK
}

\begin{abstract}
This paper provides evidence of the impact of the new European bank resolution regime on the sovereign-bank nexus. The implementation of the Bank Recovery and Resolution Directive (BRRD) is considered as an exogenous shock which provides the setting for a natural experiment. This investigation tests the financial markets' perception of the effectiveness of the new rules in weakening the tight interconnectedness between sovereign and bank risk. A Difference-in-Differences (DiD) approach is adopted, building evidence from the Credit Default Swap (CDS) market for banks and nonfinancial corporates over the period 2011-18. The main findings do not indicate a significant weakening in the interaction between bank and sovereign CDS spreads, compared to the corresponding evidence for the non-financial corporate sector. An overall narrowing of the gap between bank and sovereign risk occurs, which initially implies a lack of credibility of the BRRD in financial markets. However, substantial cross-country variations are identified, particularly for Italy and non-euro area countries. These insights make a significant contribution to the policy debate on effective regulation of the sovereign-bank nexus, in the light of recent developments in the EU postcrisis reform agenda.
\end{abstract}

Resubmitted on $10^{\text {th }}$ July 2019.

The authors are very grateful for comments and suggestions received from the editor and two anonymous reviewers. The paper also benefited from comments received at the 2017 Financial Intermediation Network of European Studies, Trani.

Keywords: BRRD, sovereign-bank nexus, CDS.

JEL classification: G21, G28.

No competing interests to declare. The paper is not under consideration for any other journal.

\footnotetext{
* Corresponding author.E-mail address: livia.pancotto@strath.ac.uk
} 


\section{Introduction}

"Resolution is a collective action problem and to make it effective the various stakeholders need to have ex ante clarity and confidence on the rules of the game" (Enria, 2015)

The sovereign-bank nexus attracted widespread attention during and after the European sovereign debt crisis (e.g. De Bruyckere et al., 2013; Acharya et al., 2014; Farhi and Tirole, 2017). Concerns surrounding this phenomenon motivated the European Banking Union (BU) project and its three main pillars, i.e. Single Supervisory Mechanism (SSM), Single Resolution Mechanism (SRM) and European Deposit Insurance Scheme (EDIS). The spectrum of common rules, which apply to all EU Member States, are the Capital Requirements Regulation (CRR) and fourth Capital Requirements Directive (CRD) approved in 2013, the Directive on Deposit Guarantee Schemes (DGSs) adopted in 2014, and the Bank Recovery and Resolution Directive (BRRD) agreed in 2014 and which came into force in January $2015 .{ }^{1}$ The BRRD represents a vital step in safeguarding financial stability in Europe, particularly in mitigating moral hazard and other issues associated with a strong reliance on public bailouts (Benczur et al., 2017; Hüser et al., 2018).

The BRRD introduced a common framework to quickly and effectively wind up failing European banks and investment firms. ${ }^{2}$ It entails four key elements: (i) the preparation and prevention of failures through recovery and resolution planning ("living wills"); (ii) early intervention powers; (iii) the application of resolution tools and powers in a case of bank failure; and (iv) coordination between national authorities. ${ }^{3}$ The range of resolution instruments includes the sale of business, the creation of a bridge institution, the asset separation and the bail-in mechanism. The new regime aims to protect taxpayers' money and avoid costly state-funded bailouts, while maintaining market discipline. ${ }^{4}$

To facilitate orderly resolutions, the BRRD prescribes that institutions are also required to maintain, at all times, a robust minimum requirement for own funds and eligible liabilities (MREL) as a percentage of their total liabilities and own funds. This requirement is set in order to prevent the possibility of a liability structure that undermines the effectiveness of the bail-in or other resolution instruments, and to reduce the risk of spillover or a bank run. Therefore, the MREL ensures adequate loss absorbing capacity, which in turn should permit an orderly resolution, without causing financial

\footnotetext{
${ }^{1}$ Regulation (EU) No 575/2013, Directive 2013/36/EU, Directive 2014/49/EU and Directive 2014/59/EU, respectively. ${ }^{2}$ In the euro area, the BRRD has been implemented through the SRM. The BRRD applies to all credit institutions and large investment firms, including their EU incorporated holding companies and subsidiaries (Article 1).

${ }^{3}$ Banks are required to prepare and maintain recovery plans which indicate the measures to be adopted in various potential risk scenarios. Resolution authorities, in cooperation with supervisory authorities, are required to develop resolution plans for individual banks.

${ }^{4}$ Bank's shareholders and creditors (junior, unsecured senior and insured depositors above $€ 100.000$ ) must bear losses equivalent to at least $8 \%$ of the bank's liabilities, including own funds. Writing down and/or converting stakeholders' claims into equity represents a precondition for access to the national resolution fund or to direct recapitalization via the European Stability Mechanism (ESM), up to 5\% of the bank's total liabilities.
} 
instability and the recourse to public money. Overall, the BRRD is considered as a paradigm shift, which marked the end of the culture of bail-out and the beginning of the culture of bail-in. In principle, large European countries with solid public finances can no longer provide implicit subsidies of public support to their national banks, therefore eliminating a potential source of competitive advantage. Similarly, countries with weak public finances and smaller institutions are no longer able to support and promote their national champions (e.g. Constâncio, 2014).

In this context, the implementation of the BRRD can be considered as an exogenous shock, which involved the whole European banking sector. This event provides the setting for a natural experiment to test financial market perceptions about the effectiveness of the new resolution rules in weakening the sovereign-bank nexus. The success of the new regime to resolve banks requires that financial markets perceive it as credible and effective (Huertas, 2016). If there is no confidence that bank failures can be managed in an orderly manner and market participants still expect government intervention, the resolution procedure could lead to major and more severe turmoil. Reinforced legal and factual certainty can engender confidence at a time of distress, while restoring market discipline and appropriate pricing during normal times (Enria, 2015). Effective and credible resolution regimes are therefore crucial not only to minimize the costs associated with bank failures, but also to reduce the ex ante probability of default by incentivising more prudent behaviour (Ignatowski and Korte, 2014). To some extent, the issue of credibility has arisen in the Italian cases of two Veneto banks and the state aid to Banca Monte dei Paschi Siena SpA. ${ }^{5}$

This paper investigates the impact of the new EU resolution regime upon the sovereign-bank nexus. Drawing evidence from the Credit Default Swap (CDS) market, we exploit the introduction of the BRRD and employ Difference-in-Differences (DiD) estimation where banks act as the treatment group and non-financial corporates as the control group. ${ }^{6}$ The main hypothesis underlying the analysis is that the intervention was expected to impact the sovereign to non-sovereign link in the case of banks (treated entities), while leaving unaffected the sovereign-corporate link. In this light, a reduced interconnection between sovereign and bank CDS spreads was anticipated. To preview the main findings, there are indications that market participants did not assess the implementation of the BRRD as credible in loosening the negative loop between sovereign and bank risk. These inferences are robust to using alternative model specifications and country groupings. However, in support to initial predictions, substantial variation is revealed across countries. In particular, the strongest credibility of the regime is revealed in Italy, whereas counter-intuitive results are reported for non-euro area countries.

\footnotetext{
${ }^{5}$ In June 2017, Banca Popolare di Vicenza SpA and Veneto Banca SpA were rescued by the Italian government with an injection of $€ 17 \mathrm{bn}$. In July 2017, the European Commission (EC) approved $€ 5.4 \mathrm{bn}$ in state aid for the precautionary recapitalisation of Banca Monte dei Paschi di Siena SpA.

${ }^{6}$ As the setup for a DiD estimation is appropriate, we constructed our empirical strategy in a similar fashion to Ignatowski and Korte (2014), Fiordelisi et al. (2017), Gropp et al. (2019), among others.
} 
The paper offers the following key contributions to the existing literature. We provide new insights into recent policy debates on how to effectively weaken the sovereign-bank nexus in Europe and avoid its reignition. Unlike prior literature (e.g. De Bruyckere et al. 2013; Breckenfelder and Schwaab, 2018; Fratzscher and Rieth, 2019), which focuses on the determinants and relevance of the main transmission channels between bank and sovereign risk, our paper investigates how financial market participants evaluate the implementation of the BRRD as a means to weaken the sovereignbank nexus. To this extent, our results point towards the importance of adopting credible and consistent rules, which can be easily assessed by financial markets. The existence of discrepancies in implementation could undermine the effectiveness of the new bank resolution regime. Furthermore, the existing differences among countries are likely to influence market participant perceptions, especially when considering cross-border banks. Fostering greater harmonization and cooperation is therefore crucial to achieve a credible and effective resolution framework.

In addition, our analysis contributes to the very limited empirical evidence on the new bank resolution regime in Europe. Whereas Conlon and Cotter (2014), Schäfer et al. (2016), Benczur et al. (2017) and Hüser et al. (2018) focus on the bail-in mechanism, this paper is unique in addressing the overall EU resolution framework and its effectiveness. The evidence supports calls for a timely completion of the wider project of $\mathrm{BU}$ in Europe and to some extent provides rationale for revisions to the BRRD, consistent to those of the 2019 EU banking package. ${ }^{7}$ Weakening the sovereign-bank nexus, while preserving financial stability, represent the main objectives of the ongoing post-crisis regulatory reforms in Europe. Our findings advance the debate on these issues.

The remainder of the paper is organized as follows. Section 2 reviews the relevant literature on the sovereign-bank nexus in Europe. Section 3 discusses the data, the identification strategy and the empirical methodology. Section 4 outlines the main hypotheses. Section 5 reports the empirical results and Section 6 concludes the paper.

\footnotetext{
7 Proposed in November 2016 by the EC, and approved in April 2019 by the European Parliament (EP), the banking package includes reforms which aim to make the European banking sector more resilient and able to withstand potential shocks. The amendments involve the CRR/CRD, the BRRD and the SRM regulation.
} 


\section{Evidence on the sovereign-bank nexus}

The strong inter-linkage between bank and sovereign risk emerged as a troublesome feature of the European sovereign debt crisis, which started in Greece in late 2009. Bolton and Jeanne (2011, p.5) state that "financial integration, bank fragility and contagion have been at the core of the crisis". The spillover between government and bank credit risk occurred in both directions with the potential for mutual contagion effects. ${ }^{8}$ Weakening this powerful interconnection, which still represents a key element of the post-crisis regulatory reform agenda, would improve countries' economic resilience and strengthen banks (Laeven, 2019).

For 2007-10, Acharya et al. (2014) provide empirical evidence for a two-way feedback between sovereign and bank risk in the euro area. Specifically, these authors highlight a significant post-bailout co-movement between the CDS spreads of sovereigns and financial firms. Alter and Shuler (2012) examine the interaction of the default risk for seven euro area countries and their domestic banks for 2007-10. They suggest that the pre-bailout direction of spillover is from the financial sector to sovereign, while during the post-bailout period government CDS spreads are the drivers of banks' CDS spreads. Dieckmann and Plank (2012) find evidence of a public-to-private risk transfer in European countries providing government support to their banking systems. In addition, they argue that this transfer is more significant in euro area countries due to their higher sensitivity to the health of the integrated financial system.

During periods of banking crisis, the implicit public guarantees to the domestic sector assume an influential role, inducing negative consequences for sovereign risk (Gerlach et al., 2010; Laeven, 2019). Bicu and Candelon (2013), employing BIS cross-border data on banking exposures and CDS spreads, investigate the potential spillover between bank and sovereign distress in the euro area, with a focus on the importance of direct and indirect financial exposures. They note that indirect connections represent a significant channel for risk transfer and that aggregate vulnerabilities of national banking systems are underestimated when these links are not considered. De Bruyckere et al. (2013) document the presence of contagion between bank and sovereign credit risk in Europe for 2007-12. These authors provide evidence of the existence of multiple risk transmission channels (i.e. asset holding channel, guarantee channel and collateral channel) and highlight some bank- and countryspecific variables that potentially drive contagion.

Avino and Cotter (2014) assess the relationship between sovereign and bank CDS spreads, focusing on the ability of these indicators to provide timely signals of the potential default risk of European governments and their banking systems. For six European countries in 2004-13, the authors

\footnotetext{
${ }^{8}$ There are four main channels through which sovereign risk affects banking risk (BIS, 2011). Some work via the asset side of bank balance sheets, whilst others are on the liabilities side (Angelini et al., 2014; Laeven, 2019). As observed in Iceland (2008), Ireland (2008) and Cyprus (2013), contagion can occur in either direction.
} 
find evidence of inter-linkages between sovereigns and their respective banking sectors. Furthermore, in investigating the underlying price discovery mechanism, they document cross-country differences over time. In more stable countries (Germany and Sweden), bank CDS spreads show a leading role over the entire sample period, while in the case of peripheral distressed economies (Portugal and Spain), the leading role is assumed by sovereign CDS spreads, during both the sub-prime and European sovereign debt crises.

Alter and Beyer (2014) propose an empirical approach to measure the spillover effects between sovereign credit markets and systemically important banks in the euro area. Using bank and sovereign CDS spreads for 2009-12, they document increasing spillovers (and potential contagion) before key financial market episodes and policy actions during the European sovereign debt crisis. In addition, they argue that the peripheral countries' contribution to systemic risk is high before their bailouts but then decreases rapidly. Spillovers from sovereigns to banks, and vice versa, tend to increase during periods of turmoil, reflecting the close bank-sovereign link in the euro area.

Farhi and Tirole (2017) develop a theoretical framework to assess the risk loop between banks and their respective sovereigns. They identify that a weak banking sector can negatively affect the level of sovereign indebtedness because of potential bailouts, which increase the stock of public debt. At the same time, a weak sovereign has a direct effect on the health of domestic banks because of their holdings of government debt. The magnitude of the effect depends on the extent of banks' home bias in asset holdings. They also provide a rationale for externalizing the function of banking supervision (a key pillar in the structure of a banking union). Breckenfelder and Schwaab (2018) analyse the spillover effect between bank and sovereign risk in the euro area. In a multi-country framework, they provide evidence of the existence of a significant cross-border component in explaining the nexus between bank and sovereign distress. Cooper and Nikolov (2018) develop a model to evaluate the feedback loop between banks and sovereigns, while suggesting different remedies to break this negative nexus, including the imposition of capital requirements on sovereign exposures. Fratzscher and Rieth (2019) use CDS data for 2003-13 to explore the link between sovereign and bank default risk in the euro area. They find evidence of a two-way causality between adverse shocks at sovereign and bank level, with the sovereign distress being more relevant in explaining bank fragility than vice versa. The authors also confirm that bank bailouts lowered the level of credit risk in the banking system, whilst raising sovereign risk. Laeven (2019) assesses the elements of the EU post-crisis regulatory response to the sovereign-bank nexus, while suggesting the adoption of a holistic approach in order to avoid undesired consequences.

Despite this recent literature on the sovereign-bank nexus and its determinants, there remains a void whereby no empirical studies have yet investigated the credibility of the new EU bank resolution regime in terms of financial market connections among sovereigns, banks and the corporate sector. 


\section{Data and Methodology}

\subsection{Data}

We employ daily CDS data for European sovereigns and corporates (both financial and nonfinancial), sourced from Datastream. As standardized products with pre-specified and comparable terms, CDS contracts allow for a reliable comparison of credit risk across corporates and sovereigns (Breckenfelder and Schwaab, 2018). Specifically, 5-year CDS mid-quotes on senior unsecured debt contracts are selected, because this type of contract is commonly considered to be the most liquid and to represent the largest share of the CDS market (Ballester et al., 2016; Black et al., 2016). The restructuring clause is the full-restructuring credit event (CR) for the sovereign entities and the modified-modified restructuring ( $\mathrm{MM}$ ) clause for the non-sovereign entities, which correspond to the standard (and, therefore, most liquid) conditions for CDS contracts traded on European reference entities (Bedendo et al., 2015). ${ }^{9}$ The sample period spans from July 2011 to June 2018, which enables symmetric periods before and after the most crucial date in the establishment of the BRRD regime.

There is a lack of discussion about CDS data in many previous research papers using European data. Mayordomo et al. (2014) compare five main databases for CDS prices, i.e. GFI, Fenics, Reuters, CMA and Markit. Using 5-year CDS included in the European iTraxx and in the US CDX, they investigate the consistency across the data sources in both the cross-section and time series dimensions, for 200410. They underline the existence of non-random deviations from the common trend across different datasets. Following a detailed investigation of different sources, our paper only employs data from Datastream in the interests of reliability and consistency. ${ }^{10}$

Data selection for a given EU country is dependent on the existence of CDS prices for the sovereign and for at least two non-sovereign entities. ${ }^{11}$ The initial sample comprises CDS data on 196 entities (142 non-financial and 54 financial). ${ }^{12}$ After excluding any series with missing observations, the resulting sample comprises 187 entities (133 non-financial and 54 financial) across 12 countries (Austria, Belgium, Germany, Finland, France, Ireland, Italy, Netherlands, Portugal, Spain, Sweden and the United Kingdom). Observations from the UK account for $30 \%$ of the dataset, and France and Germany, around $19 \%$ and $18 \%$, respectively. ${ }^{13}$

\footnotetext{
${ }^{9}$ Any currency differences can be ignored as CDS data are expressed as a rate, thus without units (Ang and Longstaff, 2013; Buchholz and Tonzer, 2016).

${ }^{10}$ We highlight the possibility of discrepancies among the price series provided by different data providers. This arises because CDS price data are collated from different contributors (e.g. brokers) based on their voluntary participation in periodic surveys. Leland (2009) reports that Bloomberg's CDS data is often revised later and can differ substantially from other data sources such as Datastream.

${ }^{11}$ Finland, Ireland and Portugal are not included on a single basis, but only in the cross-country analysis, due to the limited CDS data either for non-financial or financial firms. Greece was not included in the sample due to its disrupted sovereign CDS data for 2012-13 (see Greenwood-Nimmo et al., 2019).

12 The qualifying non-financial corporates are from the following sectors: (i) consumer goods; (ii) utilities; (iii) energy; (iv) manufacturing; (v) services; (vi) telecommunications; and (vii) transportation.

${ }^{13}$ To reduce the impact of outliers, both sovereign and non-sovereign CDS spreads are winsorized at the $1 \%$ level in each tail of the distribution. Moreover, in considering the relation between sovereign and non-sovereign CDS spreads,
} 
Figure 1 presents the time series of sovereign and non-sovereign CDS spreads for nine of the selected countries over the entire sample period. More distressed countries, such as Italy and Spain, show higher (and more volatile) prices than the other countries. This is particularly evident during the most acute phase of the European debt crisis, i.e. between August 2011 and August 2012 (Ongena et al., 2016). Sovereign CDS spreads are visibly lower than the other two time series for all the other countries.

Table 1 provides descriptive statistics for each CDS price series (sovereigns, banks and nonfinancial corporates) for the full time period (Panel A) as well as for the pre-and post-BRRD periods (Panels B and C). There is considerable heterogeneity in the sample, both across time and across countries. Panel A shows that euro area peripheral countries demonstrate the highest average CDS spreads over the entire sample period. In contrast, the lowest average spreads are in Germany (16.93 bps) and Sweden (17.58 bps). In the banking system, the average value for all the countries is above 105 bps except for Sweden (73.40 bps). Average CDS prices for Irish and Portuguese banks are the highest. Finally, Italian non-financial companies have the highest average of daily CDS price (255.76 bps), followed by Finnish and Spanish corporates (176.72 and 165.72 bps, respectively). A substantial reduction in the average values, for both sovereign and non-sovereign entities, is clear when comparing the data for pre- and post-BRRD implementation (Panels B and C of Table 1).

\subsection{Methodology}

To draw inference on the impact of the BRRD implementation on the CDS market and on the link between European banks and the respective sovereigns, we adopt a DiD estimation approach. The major assumption underlying the DiD methodology is that the average change in the outcome is expected to be the same for both the non-treated cohort and, counterfactually, for the treated cohort had the latter not participated. Unmeasured factors, such as changes in the economic environment, are therefore assumed to similarly affect both treated and non-treated entities (i.e. parallel trends assumption).

These principles apply in our context in the following manner. In the absence of the treatment (BRRD), the behaviour of bank CDS (i.e. treatment group) would have evolved similarly to that of the non-financial corporate CDS (i.e. control group). Figure 2 displays the trend over the years 2011-14 (pre-treatment period) for the average CDS spreads for banks, non-financial firms and related sovereigns. From a visual inspection, we infer that the parallel trends assumption holds since both the treated and untreated groups approximately exhibit a common trend in the absence of intervention. ${ }^{14}$

there were some instances when the former exceeds the latter. This condition is difficult to be economically justified, especially after investigating the associated issuer credit ratings. For the results reported in the paper, these specific price observations were considered to be missing.

${ }^{14}$ In order to further assess the plausibility of the parallel trend assumption, we conducted a placebo test employing a treatment group randomly selected from the control group. We found that the intervention did not have a significant impact on the "fake" treatment group, which supports the parallel trend assumption. 
The main treatment (intervention) is represented by the BRRD which came into effect on $1^{\text {st }}$ January 2015. Moreover, an earlier intervention date (i.e. $15^{\text {th }}$ May 2014 - the enactment date of the BRRD) has also been used in robustness tests. ${ }^{15}$ The entire data sample is drawn from European countries subject to BRRD requirements. We conduct the analysis on all the countries pooled together and on some specific groupings of countries.

The model specification captures the effect of the intervention on the CDS market and on the sovereign-bank nexus. The following equation shows the baseline model:

Equation 1

$$
\mathrm{GAP}_{\mathrm{i}, \mathrm{t}}=\alpha_{0}+\beta_{1} \mathrm{BRRD}_{\mathrm{t}}+\beta_{2} \text { Treat }_{\mathrm{i}}+\beta_{3} \mathrm{BRRD}_{\mathrm{t}} \times \text { Treat }_{\mathrm{i}}+\varepsilon_{\mathrm{i}, \mathrm{t}}
$$

where $\mathrm{GAP}_{\mathrm{i}, \mathrm{t}}$ is the difference, in price levels, between the non-sovereign CDS spreads and the sovereign CDS spreads (henceforth, "GAP"). $i$ indexes the firm and $t$ indicates time. BRRD and Treat are binary variables. BRRD represents the treatment and is equal to one from $1^{\text {st }}$ January 2015 to $30^{\text {th }}$ June 2018 and zero otherwise. Treat equals zero for the control group (i.e. non-financial corporates) and one for the treatment group (i.e. banks). $\alpha_{0}$ represents the level of GAP in the control group prior to the treatment. $\beta_{1}$ captures any change in GAP in the control group following the BRRD implementation. $\beta_{2}$ captures GAP differences between the treatment and control groups before the intervention. $\beta_{3}$ represents the main coefficient of interest, because it captures the effect of the intervention on the treatment group. More specifically, it measures the difference in the GAP from the pre-treatment to the post-treatment period, between banks relative to non-financial corporates. A positive (negative) and statistically significant coefficient for $\beta_{3}$ would imply ceteris paribus that the GAP widens (narrows) more for banks than non-financial corporates.

We augment our baseline equation into that considered as preferred, which includes a binary variable to control for the European sovereign debt crisis, a set of market-wide control variables and firm-specific fixed effects:

Equation 2

$$
\mathrm{GAP}_{\mathrm{i}, \mathrm{t}}=\alpha_{0}+\beta_{1} \mathrm{BRRD}_{\mathrm{t}}+\beta_{2} \mathrm{BRRD}_{\mathrm{t}} \times \text { Treat }_{\mathrm{i}}+\beta_{3} D_{\text {crisis }}+X_{t}+\gamma_{i}+\varepsilon_{\mathrm{i}, \mathrm{t}}
$$

Equation [2] subsumes the effect of Treat in the firm fixed effects (Cerqueiro et al., 2016). $D_{\text {crisis }}$ equals one between July 2011 and September 2012, and zero otherwise. $X_{t}$ accounts for market-wide factors, such as general business climate changes (e.g. Sclip et al., 2019), aggregate volatility (e.g. Annaert et al., 2013) and market-wide variations in CDS spreads (e.g. Acharya et al., 2014). Daily logarithmic returns for the Stoxx Europe 600 Index and the DS iTraxx Europe 5Y Index are included, as well as daily changes for the Vstoxx Index (these variables are added alternately to avoid collinearity

\footnotetext{
15 In addition, a further robustness test using a later intervention date of $1^{\text {st }}$ January 2016 was conducted (with this date chosen because it was the required date for full implementation of the bail-in tool under the BRRD). The inferences are unaffected by this choice of date, hence only the results for two dates are presented in the paper.
} 
issues). $\gamma_{i}$ are firm fixed effects, which rule out the influence of unobserved firm specific differences constant over time. Robust standard errors are clustered at firm level to control for potential serial correlation within each panel. ${ }^{16}$

The crisis period is defined as prior to $1^{\text {st }}$ September 2012, which represents a date of compromise between the three key dates associated with the ECB Outright Monetary Transactions (OMT) program. ${ }^{17}$ Several authors (among others, Ferrando et al., 2015; Zaghini, 2016; Acharya et al., 2017) acknowledge that the announcement of the OMT by the ECB in summer 2012 reduced tensions in both the euro area banking system and sovereign debt market. Announcement of the bond-buying program had an immediate positive impact in lowering spreads on sovereign bonds issued by distressed European countries. Many authors (e.g. Altavilla et al., 2016; Krishnamurthy et al., 2018) find that the ECB's unconventional monetary policy reduced peripheral sovereign bond yields, particularly for countries such as Italy and Spain. The consequent increase in the value of these securities contributed to restoring the stability of the European banking system. The ECB's intervention, which aimed to ease tensions and lowering the pricing of extreme risks (i.e. the collapse of the euro area), resulted in improved market access for both sovereigns and corporates from mid2012 (Zaghini, 2016). Fratzscher and Rieth (2019) consider the announcement of the OMT program to have been the most effective measure in reducing default risks in the euro area, both at sovereign and bank level. Finally, in order to add robustness to our results and inference, estimation of the preferred specification (Equation 2) is conducted using alternative data frequencies (i.e. daily, weekly and monthly). ${ }^{18}$

\section{Hypotheses}

Public rescues of troubled banks are a source of moral hazard and they undermine market discipline (Acharya and Yorulmazer, 2008; Dell'Ariccia et al., 2018). Bailouts create expectations about future government responses to financial turmoil. More specifically, the subsidization of bank stakeholders' risk-taking, through the externalization of the costs connected to failures, exerts a distorting effect on ex ante incentives. This could potentially create instability, fragility and risk in the banking sector (Hadjiemmanuil, 2017). Moreover, state-funded bailouts of insolvent banks produce a severe destabilizing effect on public finances and sovereign indebtedness. ${ }^{19}$ In order to overcome the

\footnotetext{
${ }^{16}$ Moreover, country fixed effects are also considered in an alternative specification. A pertinent illustration of using such alternatives in a DiD framework can be found in Fiordelisi et al. (2017). The results presented in Section 5 are based on the preferred model specification (Equation 2).

17 On $26^{\text {th }}$ July 2012, the ECB President Draghi stated, during a conference in London, that the ECB was ready to do "Whatever it takes to preserve the Euro". On $2^{\text {nd }}$ August 2012, there was the announcement of the launch of the OMT Program, while its technical features were officially presented on $6^{\text {th }}$ September 2012.

${ }^{18}$ In the interests of brevity, the results are presented in full for the daily frequency and partially for the weekly data frequency.

${ }^{19}$ During 2008-14, the direct fiscal costs associated with the banking crisis accounted for $4.8 \%$ of euro-area GDP (ECB, 2015).
} 
implicit principle of resolution, which characterized the crisis period and led to the privatization of banks' profits and the socialization of their losses, there were two major responses at the European level. Firstly, based on the BRRD, a clear framework for dealing with failing banks was established, together with a central responsible resolution authority (i.e. the SRM). Secondly, the potential burdens of bank failure were realigned such that they would be borne by shareholders and bondholders, rather than by taxpayers. The bail-in concept was introduced with the intention of eliminating calls on the bailout mechanism (Benczur et al., 2017).

The successful application of the new resolution rules requires that financial markets perceive them as credible and effective. If there is no confidence that a bank failure can be managed in an orderly fashion and market participants still expect a public bailout, the resolution procedure could lead to further turmoil. In this light, some authors (Avgouleas and Goodhart, 2015; Dell'Ariccia et al., 2018) suggest that the bail-in mechanism might be inappropriate in the case of a systemic banking crisis. The bail-in approach might work better than bailout policies in the case of idiosyncratic distress, but not when there is a threat of systemic crisis or in the event of the collapse of a large cross-border European institution. Eventually, it might also intensify the potential systemic effect of a minor idiosyncratic turbulence (Navaretti et al., 2016). De Grauwe (2013) suggests that the new resolution framework could increase systemic risk in the euro area, thus making banking crises more likely, as a consequence of bank runs and large economic costs associated with the bail-in mechanism. The author emphasizes the negative effect of the bail-in provision on deposit holders. ${ }^{20}$

In investigating whether the new bank resolution rules had an impact in weakening the doom loop between banks and sovereigns in Europe, the main hypothesis underlying our analysis is that the intervention is expected to impact the nexus in the case of banks, whereas the sovereign-corporate link should not be affected. ${ }^{21}$ The underlying assumption is that, a priori, the link between sovereigns and banks (regardless of the direction of causality) is considered as special compared to that between sovereigns and non-financial firms. Therefore, a lowering in the potency of the nexus between sovereign and bank risk, measured by CDS spreads, is anticipated. A relative widening of the GAP variable for banks, as described in Section 3.2, is expected if the BRRD is perceived as credible by market participants. A priori, we expect this to be especially evident in peripheral euro area countries. If the BRRD is not perceived as effective and reliable, the gap between bank and sovereign CDS spreads might, instead, be not significantly changed or decrease.

\footnotetext{
${ }^{20}$ Under the BRRD, the bail-in of the most junior depositor class remains a possibility. Specifically, as per Moody's (2015), the BRRD establishes a hierarchy in liquidation between different categories of deposits: those protected by deposit protection schemes ("covered deposits", most senior), deposits by individuals and SMEs which are eligible for protection but exceed the maximum amounts ("eligible and uncovered", second most senior) and finally other deposits, essentially from large corporates and institutions (junior deposits).

${ }^{21}$ In this context, it is worthwhile to mention that non-financial corporates with traded CDS are commonly large, bluechip companies, with relatively little reliance on the bank credit channel (Angelini et al., 2014).
} 


\section{Empirical results}

This section provides results for the analysis conducted on the pooled sample of EU countries, as well as on a selected number of country sub-samples. This approach is motivated by the aim of better capturing and explaining the specific dynamics of economies with more homogenous features (e.g. euro area countries). The first stage of the investigation considers two alternative intervention dates, i.e. $15^{\text {th }}$ May 2014 and $1^{\text {st }}$ January 2015, and is conducted on both daily and weekly data frequencies. This enables the selection of the most relevant intervention date and ensures that potential illiquidity noise in the daily CDS market data does not influence the main findings.

Panel A of Table 2 displays the estimation results for the preferred model specification (Equation 2), for daily data, when adopting $1^{\text {st }}$ of January 2015 as the treatment date. In all cases, the coefficient on the main variable of interest (i.e. BRRD $x$ Treat) is negative and with a marginal statistical significance at the $10 \%$ level. This evidence suggests a more pronounced narrowing in the GAP variable for banks than for non-financial corporates (following the intervention). Therefore, in contrast to the prior expectations, it seems that market participants did not assess the implementation of the BRRD as credible in loosening the negative loop between sovereign and bank risk across Europe. Accounting for firm fixed effects adds robustness to the evidence, while supporting the idea of a relatively wide heterogeneity across corporates. In contrast, heterogeneity across countries initially appears to be more limited. The crisis episode has a meaningful effect in explaining the variation in the dependent variable, confirming the strong impact that the European sovereign debt crisis had on both the real economy and financial markets. The control variables included in the specification, with the aim of accounting for market-wide variations, have no substantive impact on the main findings of interest.

Panel B of Table 2 presents the estimated coefficients, for daily data, when adopting $15^{\text {th }}$ May 2014, the BRRD enactment date, as alternative intervention date. In this setting, the coefficient on the variable measuring the DiD effect (i.e. BRRD $x$ Treat) maintains a negative sign, which is statistically significant at the $5 \%$ level. This evidence confirms a narrowing in the dependent variable GAP which is more marked in the banking sector than in the non-financial sector. These results confirm the presence of a relatively high level of heterogeneity across firms and the influence of the crisis episode. Overall, the evidence from employing an alternative intervention date does not diverge substantially to that arising when using the originally selected intervention date..$^{22}$

In order to account for any liquidity noise in the price data, a similar empirical strategy is adopted on weekly data. Results for the estimation employing the two alternative, but related, intervention

\footnotetext{
${ }^{22}$ To reinforce the selection of the original intervention date, we conducted a further falsification test and repeated the DiD estimation with a later alternative intervention date, i.e. $1^{\text {st }}$ January 2016 . The results do not indicate a significant DiD effect for the treated group relative to the control group. This evidence also rules out the possibility that the significant change in the outcome of interest was driven solely by the introduction of the bail-in tool, whose provision under the BRRD came fully into force on $1^{\text {st }}$ January 2016. In the interests of brevity, this set of results is not reported in the paper.
} 
dates are presented in Panels C and D of Table 2. No specific evidence of illiquidity is revealed and the results are consistent for the alternative data frequencies. Moreover, no significant divergences are highlighted when using the two intervention dates. Based on this evidence, and to avoid repetition, the remaining reported results reflect the use of daily data and the adoption of $1^{\text {st }}$ January 2015 as the treatment date.

In reflecting on the above findings, it is possible to identify several potential reasons for a clear divergence from our prior expectations. Firstly, weakening the sovereign-bank risk nexus could be limited by the fact that most EU banks still held large amounts of their own sovereign debt. As of June 2015, according to the EBA EU-wide transparency exercise, EU banks held $€ 2$.3tn in government debt and $65 \%$ of these exposures were to domestic sovereigns. The latter home bias problem represents a crucial obstacle to the implementation of a EDIS, which is a fundamental step towards weakening the sovereign-bank nexus and completing the BU. Therefore, revisiting the regulatory (preferential) treatment of sovereign exposures and the related concentration limits, with the final aim of avoiding large-scale public bailouts, is central to the policy debate (Andritzky et al., 2016). ${ }^{23}$ From this perspective, the more comprehensive approach suggested in Laeven (2019) could enable a more thorough weakening of the sovereign-bank nexus.

Moreover, some flexibility in the use of the bail-in tool with the aim of preserving financial stability, as established under the BRRD and the EU norms on state aid, might entail sufficient political influence such as to threaten the credibility of the resolution mechanism. ${ }^{24}$ Thus, discretionary exceptions should be permitted only under extraordinary and precisely defined conditions (Buch, 2016). The scope for interpretation should be reduced in order to avoid legal uncertainty and to ensure the effectiveness of the resolution framework (Philippon and Salord, 2017).

In Moody's (2015) view, national deviations from the EU-BRRD led to a more complex and fragmented framework able to delay the process of resolving banks, while making the outcomes less predictable for market participants. ${ }^{25}$ In addition, there was a significant delay in the implementation of the BRRD across countries. As of June 2015, while the BRRD should have entered in force from January 2015, some of the selected EU countries were still transposing it into national law (e.g. France, Italy, Netherlands, Spain, and Sweden). ${ }^{26} \mathrm{~A}$ potential effect of such a delay is the risk that a bank failure in a country where the BRRD is not fully implemented might result in a conflict between EU and national law, with an associated high legal risk.

\footnotetext{
${ }^{23}$ Positive risk weights would tackle counterparty credit risk, while large exposure limits would tackle concentration risk. Proposals about the subjection of banks' sovereign exposures to capital requirements and/or large exposure limits were examined by the ECOFIN in April 2016.

${ }^{24}$ On the state aid rules to support measures in favour of banks, see the 2013 EC "Banking Communication".

${ }^{25}$ Germany and Italy, for instance, have modified the BRRD script by supplementing the hierarchy that defines which asset classes suffer the first losses in the case of a bank failure (Moody's, 2016).

${ }^{26}$ Refer to the ISDA BRRD Implementation Monitor (http://www2.isda.org/isda-brrd-implementation-monitor/).
} 
Another consequence, which negatively affects investors, arises from the persistent uncertainty about the insolvency hierarchies that apply in the case of a bank failure. According to Fitch (2016), the use of exemptions can lead to more complex resolutions due to increased legal risk and compensation costs. Indeed, under the BRRD, in exceptional circumstances the resolution authority can discretionally decide to exclude, fully or partially, certain instruments from the bail-in, based on their maturities and/or holders. The lack of an EU standard defining this exceptionality might imply different interpretations of these options across different jurisdictions. The possibility that bail-in cases would proceed heterogeneously in each EU Member State represents a potential source of uncertainty for market participants, while raising the cost of banks' funding (Huertas, 2016). As Fitch (2016) reports, bailing-in senior liabilities with a retail investor base might result in a difficult and politically sensitive task for resolution authorities. The prospect of unequal treatment of creditors within the same class can lead to significant legal consequences, as observed in the cases of Portuguese Banco Espirito Santo and four small Italian banks at the end of $2015 .{ }^{27}$

In addition, in a weak banking context characterized by widespread distress, the bail-in of a single institution may induce other banks' claimholders to review their positions, with a consequent "flightto-quality" effect. This, in turn, might imply a significant increase in the cost of funding for the whole banking sector (Hadjiemmanuil, 2017). Together with potential contagion arising from market reactions, the more direct transmission channel of losses from the resolved bank and other institutions holding bail-inable liabilities would also be relevant. In fact, losses experienced by those institutions could harm their own viability, along with inducing negative effects for the entire financial system (Hüser et al., 2018).

Finally, the BRRD came into force during a period of high fragmentation of the EU banking system, and more generally of the euro area, as a consequence of the sovereign debt crisis. A common framework applied to markedly different contexts, characterized by different backgrounds and legal systems, could increase divergence across countries. ${ }^{28}$

\footnotetext{
${ }^{27}$ Regarding the Italian case, Ignazio Visco (Governor of the Bank of Italy) stated that when the bail-in mechanism is not adequate to achieve resolution goals and there are threats to financial stability, the possibility of public support might not be ruled out. Specifically, the confidence in the whole banking sector was weakened by the write-down of subordinated debt held by retail customers and the associated national media coverage. This, in turn, resulted in deposit outflows from weaker banks in late 2015 and early 2016 (Visco, 2016).

28 In December 2017, the European Court of Auditors reported that the Single Resolution Board (SRB) is still a work in progress and has been required to take on considerable responsibilities in a short span of time. According to SNL, the auditors also outlined shortcomings in the SRB's contingency plans for bank resolution and made a number of recommendations relating to the agency's rules, guidance and preparation on resolving failing banks.
} 


\subsection{Evidence from sub-samples of countries}

In order to reveal more detailed insights on market perceptions of the effectiveness of the BRRD, we analyse a number of country sub-samples. The underlying rationale is to investigate the market dynamics for groups of economies which have well-defined aspects of commonality. For this purpose, we report results for countries in three main categories, i.e. (i) euro area core countries; (ii) euro area peripheral countries; and (iii) large European countries (Tables 3, 4 and 5). Within these three categories, we subsequently deepen our investigation by considering further differentiations, i.e. (i) large/small euro area core countries; (ii) Italy and Spain on a separate basis; and (iii) large euro area/non-euro area countries.

Panel A of Table 3 reports the results for the analysis on the euro area core countries (defined as Austria, Belgium, Finland, France, Germany and Netherlands). The estimated coefficient on the variable of interest (i.e. BRRD $x$ Treat) is positive for all the specifications, but with no statistical significance. The contribution of the crisis event is always positive and statistically significant. The high degree of heterogeneity across firms is again confirmed. The focus on the large euro area core economies (Panel B of Table 3) reveals a negative, relatively small and non-significant coefficient of interest for all the model specifications. A different scenario, albeit not statistically significant, is presented in Panel $\mathrm{C}$ of Table 3. When considering small euro area core countries, i.e. Austria, Belgium and Finland, the coefficient on the main variable of interest is positive and large in magnitude. Moreover, the crisis event does not appear as having a significant contribution and cross-country heterogeneity assumes a more prominent role in explaining the variability in the dependent variable.

The investigation proceeds by focusing on the group of euro area peripheral economies (i.e. Ireland, Italy, Portugal and Spain). Panel A of Table 4 displays the findings for the estimation covering the entire sub-sample of peripheral euro area countries. The main coefficient of interest (for $B R R D \times$ Treat) is always negative, but with no statistical significance. A relatively high cross-country heterogeneity is highlighted and the crisis episode positively contributes in explaining the variability in the GAP. Focusing on the two peripheral countries with larger data samples, Panel B of Table 4 presents the findings for Italy, while Panel C reports those for Spain. The estimated coefficient on the variable $B R R D \times$ Treat is positive (15.572 bps) and highly statistically significant for Italy. This evidence suggests that the implementation of the BRRD was perceived by the markets as beneficial in weakening the nexus between Italian banks and their government. Indeed, a widening of the GAP variable implies a potential reduction in the potency of the interaction between sovereign and bank risk (consistent with our main hypothesis). The Italian banking system, hampered by a large volume of Non-Performing Loans (NPLS), i.e. $€ 360 \mathrm{bn}$ at the end of 2015 , and numerous fragile banks, thus 
represents a unique case. ${ }^{29}$ The reduced likelihood for these banks to be rescued could logically be captured in a widening of the gap between bank and sovereign CDS spreads. Results for Spain (Panel $\mathrm{C}$ of Table 4) reveal a large and negative coefficient on the main variable of interest, significant at the $5 \%$ level. This evidence indicates that market participants did not evaluate the BRRD as effective in loosening the sovereign-bank nexus for Spain. The crisis episode does not appear to have a meaningful contribution in the Italian context, yet for Spain seems to assume a very substantial role.

The last stage of the analysis begins with a focus on large European countries (i.e. France, Germany, Italy, Netherlands, Spain, Sweden and United Kingdom). Subsequently, we differentiate between large euro area countries (i.e. France, Germany, Italy, Netherlands and Spain) and large noneuro area countries (i.e. Sweden and United Kingdom). Table 5 reports the related findings, split across three different panels. Panel A shows that the coefficient on the main variable of interest (i.e. BRRD $\times$ Treat) is negative for all the specifications and statistically significant at $5 \%$ level. This evidence indicates an overall lack of credibility in the effect of the BRRD in weakening the interconnection between sovereign and bank risk. More specifically, it seems that the implementation of the BRRD led to a more marked narrowing in the GAP variable for banks than for non-financial firms in these countries. The findings also highlight a positive and strongly significant contribution of the crisis event. Cross-country heterogeneity does not appear to have a substantial contribution in explaining the variability in the dependent variable.

On turning attention to large euro area countries only (Panel B of Table 5), the estimated coefficients still suggest a lack of influence and lack of statistical significance associated with the BRRD implementation. The crisis event still holds its positive significance. Finally, the investigation on large European, but non-euro area countries, namely Sweden and United Kingdom, underpins what could be considered as a counter-intuitive result, to some extent. It appears that these countries are driving the results for the whole sub-group of large European countries. The coefficient on the main variable of interest (Panel C, Table 5) is negative and highly statistically significant for all the specifications. ${ }^{30}$

\footnotetext{
${ }^{29}$ See Garrido et al. (2016). The Italian government has implemented various reforms to address the issue of high levels of NPLs, including state-backed guarantees on senior tranches of securitized bad loans (so-called "GACS") and the creation of two Atlante funds with the aim of supporting capital raising and acquisition of mezzanine and equity tranches in securitization of bad loans.

${ }^{30} \mathrm{~A}$ possible interpretation of these findings, particularly related to the UK, resides in the substantial uncertainty related to the Brexit referendum vote. This led to extensive concerns on financial markets and for investors holding bank bonds. For instance, the exit of the UK from the EU creates uncertainty regarding the eligibility of bonds issued, under UK law, for MREL purposes.
} 


\section{Conclusions}

The objective of this paper is to investigate the impact of the new European bank resolution regime on the sovereign-bank nexus. Did financial market participants evaluate the bank resolution framework as an effective mechanism to weaken the link between sovereign and bank risk in Europe? Drawing evidence from the CDS market, for the period 2011-18, we used a previously unexplored natural experiment to test the effectiveness and credibility of the BRRD. We employed a DiD estimation approach where the treatment group consists of European banks, whilst the control group is composed of European non-financial corporates. Furthermore, in order to better capture potentially different market dynamics, the same empirical strategy was applied to sub-groups of countries.

The main findings, which are robust in various model specifications, did not indicate any significant weakening in the nexus between bank and sovereign CDS spreads, compared to the corresponding evidence for the European non-financial sector. Contrary to prior anticipation, an overall narrowing of the gap between bank and sovereign risk, as reflected in CDS prices, was evident. Italy was the only case where the CDS market seems to have perceived the implementation of the BRRD as effective in weakening the sovereign-bank nexus. According to the new resolution regime, a reduced probability to be publicly rescued for the Italian banks, overwhelmed by large stocks of NPLs, could be reflected in this widening of the gap between bank and sovereign CDS spreads. With hindsight, this market perception seems misplaced and over-optimistic given more recent events in the Italian banking sector.

The overall lack of confidence about the potential for the new bank resolution rules to weaken the sovereign-bank nexus might arise from multiple factors. Firstly, the persistent strong exposures of EU banks to their own sovereign debt. Moreover, the presence of several "ambiguous" provisions under the BRRD, which confer considerable discretion on the supervisory and resolution authorities, might entail sufficient political influence such as to undermine the credibility of the BRRD (Hadjiemmanuil, 2017). The bail-in provision does not completely remove the possibility of the injection of public funds where there is a threat of systemic distress or in the case of the collapse of a large cross-border European bank (Avgouleas and Goodhart, 2015). Debt holders of Global Systemically Important Banks (G-SIBs) and other institutions considered as relevant in the domestic markets might continue to benefit from a moderate probability of public support (Moody's, 2015). Finally, a weak European banking environment, hampered by extensive volumes of NPLs and low profitability, might entail the risk of reigniting the strong sovereign-bank link that characterized the sovereign debt crisis (Enria, 2017).

In sum, the reforms and policy initiatives adopted in response to both the financial and sovereign debt crises provided a robust framework to address the failure of banks across Europe. In this context, the shift from the reliance on taxpayers' money to explicitly imposing losses on the banks' 
shareholders and (unsecured) creditors represented a crucial change. However, as highlighted in various recent contributions (e.g. Enria, 2016; Laeven, 2019), additional reforms (e.g. creating both a common fiscal backstop and a common deposit insurance scheme, limiting banks' exposures to sovereign debt) must be implemented in order to further improve the resilience of the European financial system, while enhancing the consistency of the new regulatory framework. Indeed, some distance remains before achieving a situation characterized by feasible and credible plans in place to ensure an adequate level of comfort in terms of preparation for dealing with future crises (Enria, 2016). Removing embedded impediments to effective and successful resolution procedures is not immediately possible and the transition phase to a truly effective new regime poses significant challenges. Nevertheless, adhering to its key principles is essential to avoid uncertainty among market participants, ensure predictability and reduce deviations from the long-term objectives of the new institutional framework. As stated in Philippon and Salord (2017, p.41), "the old system had such a strong preference for forbearance that simply doing better is not enough". From this perspective, credibility for market participants is therefore crucial. This paper offers original insights which contribute to the policy debate. 


\section{References}

Acharya, V.V., Drechsler, I. \& Schnabl, P. 2014. A pyrrhic victory? - Bank bailouts and sovereign credit risk. Journal of Finance 69, pp. 2689-2739.

Acharya, V.V., Eisert, T., Eufinger, C. \& Hirsch, C.W. 2017. Whatever it takes: The real effects of unconventional monetary policy. CEPR Discussion Paper No. 12005.

Acharya, V.V. \& Yorulmazer, T. 2008. Cash-in-the market pricing and optimal resolution of bank failures. Review of Financial Studies 21, pp. 2704-2742.

Altavilla, C., Giannone, D. \& Lenza, M. 2016. The financial and macroeconomic effects of OMT announcements. International Journal of Central Banking 3, pp. 29-57.

Alter, A. \& Beyer, A. 2014. The dynamics of spillover effects during the European sovereign debt turmoil. Journal of Banking \& Finance 42, pp. 134-153.

Alter, A. \& Schuler, Y. 2012. Credit spread interdependencies of European states and banks during the financial crisis. Journal of Banking \& Finance 36, pp. 3444-3468.

Andritzky, J., Gadatsch, N., Körner, K., Schäfer, A. \& Schnabel, I. 2016. Removing privileges for banks' sovereign exposures - A proposal. European Economy. Banks regulation and the Real Sector 1, pp. 139-152.

Ang, A. \& Longstaff, F.A. 2013. Systemic sovereign credit risk: Lessons from the US and Europe. Journal of Monetary Economics 60, pp. 493-510.

Angelini, P., Grande, G. \& Panetta, F. 2014. The negative feedback loop between banks and sovereigns. Questioni di Economia e Finanza (Occasional Papers) No. 213.

Annaert, J., De Ceuster, M., Van Roy, P. \& Vespro, C. 2013. What determines Euro area bank CDS spread? Journal of International Money and Finance 32, pp. 444-461.

Avgouleas, E. \& Goodhart, C. 2015. Critical reflections on bank bail-ins. Journal of Financial Regulation 1, pp. 3-29.

Avino, D. \& Cotter, J. 2014. Sovereign and bank CDS spreads: Two sides of the same coin? Journal of International Financial Markets, Institutions and Money 32, pp. 72-85.

Ballester, L., Casu, B. \& González-Urteaga, A. 2016. Bank fragility and contagion: Evidence from the bank CDS market. Journal of Empirical Finance 38, pp. 394-416.

Bedendo, M. \& Colla, P. 2015. Sovereign and corporate credit risk: Evidence from the Eurozone. Journal of Corporate Finance 33, pp. 34-52.

Benczur, P., Cannas, G., Cariboni, J., Di Girolamo, F., Maccaferri, S. \& Petracco Giudici, M. 2017. Evaluating the effectiveness of the new EU bank regulatory framework: A farewell to bail-out? Journal of Financial Stability 33, pp. 207-223.

Bicu, A. \& Candelon, B. 2013. On the importance of indirect banking vulnerabilities in the Eurozone. Journal of Banking \& Finance 37, pp. 5007-5024. 
BIS, 2011. The impact of sovereign credit risk on bank funding conditions. Committee on the Global Financial System, Paper No. 43.

Black, L., Correa, R., Huang, X. \& Zhou, H. 2016. The systemic risk of European banks during the financial and sovereign debt crises. Journal of Banking \& Finance 63, pp. 107-125.

Bolton, P. \& Jeanne, O. 2011. Sovereign default risk and bank fragility in financially integrated economies. IMF Economic Review 59, pp. 162-194.

Breckenfelder, J.H. \& Schwaab, B. 2018. The bank-sovereign nexus across borders. Journal of Empirical Finance 49, pp. 247-262.

Buch, C. 2016. Completing the banking and capital markets union - where do we stand? Speech at $32^{\text {nd }}$ SUERF-Deutsche Bundesbank-IMFS Conference, Frankfurt am Main, 4 February 2016.

Buchholz, M. \& Tonzer, L. 2016. Sovereign credit risk co-movements in the Eurozone: Simple interdependence or contagion? International Finance 19, pp. 246-268.

Cerqueiro, G., Ongena, S. \& Roszbach, K. 2016. Collateralization, bank loan rates, and monitoring. Journal of Finance 71, pp. 1295-1322.

Conlon, T., Cotter, J. 2014. Anatomy of a bail-in. Journal of Financial Stability 15, pp. 257-263.

Constâncio, V. 2014, Banking Union: Meaning and implications for the future of banking. Speech at Banking Union Conference, Navarra University, Madrid, 24 April 2014.

Cooper, R. \& Nikolov, K. 2018. Government debt and banking fragility: The spreading of strategic uncertainty. International Economic Review 59, pp. 1905-1925.

De Bruyckere, V., Gerhardt, M.A., G. \& Vennet, R.V. 2013. Bank/sovereign risk spillovers in the European debt crisis. Journal of Banking \& Finance 37, pp. 4793-4809.

De Grauwe, P. 2013. Design failures in the Eurozone: Can they be fixed? LEQS Paper No. 57/2013.

Dell'Ariccia, G., Martinez Peria, M.S., Igan, D., Awadzi, E.A., Dobler, M. \& Sandri, D. 2018. Trade-offs in bank resolution. IMF Staff Discussion Note No. 18/02.

Dieckmann, S. \& Plank, T. 2012. Default risk of advanced economies: An empirical analysis of credit default swaps during the financial crisis. Review of Finance 16, pp. 903-934.

ECB, 2015. The fiscal impact of financial sector support during the crisis. Economic Bulletin No. 6/2015.

Enria, A. 2015. Challenges for the future of EU banking. Speech at III Financial Meeting organised by CECA and the Spanish Banking Association, Madrid, 14 January 2015.

Enria, A. 2016. From bank bail-outs to bail-in: Progress and open issues. Speech at Regent's University, London, 13 April 2016.

Enria, A. 2017. The European banking sector - risk and recovery. A single market perspective. Speech at ESM, Luxembourg, 30 January 2017. 
Farhi, E. \& Tirole, J. 2017. Deadly embrace: Sovereign and financial balance sheets doom loops. Review of Economic Studies 85, pp. 1781-1823.

Ferrando, A., Popov, A.A. \& Udell, G.F. 2015. Sovereign stress, unconventional monetary policy, and SME access to finance. ECB Working Paper No. 1820.

Fiordelisi, F., Ricci, O. \& Stentella Lopes, F.S. 2017. The unintended consequences of the launch of the Single Supervisory Mechanism in Europe. Journal of Financial and Quantitative Analysis 52, pp. 2809-2836.

Fitch, 2016. Retail investors complicate EU bank senior bond bail-ins. 17 June 2016.

Fratzscher, M. \& Rieth, M.H. 2019. Monetary policy, bank bailouts and the sovereign-bank risk nexus in the euro area. Review of Finance (forthcoming).

Garrido, J., Kopp, E. \& Weber, A. 2016. Cleaning-up bank balance sheets: Economic, legal, and supervisory measures for Italy. IMF Discussion Paper No. 135.

Gerlach S., Schulz A. \& Wolff, G. 2010. Banking and sovereign risk in the euro area. Deutsche Bundesbank Discussion Paper No. 09.

Greenwood-Nimmo, M., Huang, J. \& Hoang Nguyen, V. 2019. Financial sector bailouts, sovereign bailouts, and the transfer of credit risk. Journal of Financial Markets 42, pp. 121-142.

Gropp, R., Mosk, T., Ongena, S. \& Wix, C. 2019. Banks response to higher capital requirements: Evidence from a quasi-natural experiment. Review of Financial Studies 32, pp. 266-299.

Hadjiemmanuil, C. 2017. Limits on state-funded bailouts in the EU bank resolution regime. European Banking Institute Working Paper Series No. 2.

Huertas, T.F. 2016. European bank resolution: Making it work! Interim Report of the CEPS Task Force on Implementing Financial Sector Resolution.

Hüser, A., Hałaj, G., Kok, C., Perales, C. \& Van der Kraaij, A. 2018. The systemic implications of bail-in: A multi-layered network approach. Journal of Financial Stability 38, pp. 81-97.

Ignatowski, M. \& Korte, J. 2014. Wishful thinking or effective threat? Tightening bank resolution regimes and bank risk-taking. Journal of Financial Stability 15, pp. 264-281.

Krishnamurthy, A., Nagel, S. \& Vissing-Jorgensen, A. 2018. ECB policies involving government bond purchases: Impact and channels. Review of Finance 22, pp. 1-44.

Laeven, L. 2019. The regulatory response to the sovereign-bank nexus. Global Finance Journal 39, pp. 17-20.

Leland, H. 2009. Structural models and the credit crisis. China International Conference in Finance.

Mayordomo, S., Peña, J.I. \& Schwartz, E.S. 2014. Are all credit default swap databases equal? European Financial Management 20, pp. 677-713.

Moody's, 2015. European bank ratings to reflect reduced probability of government support. Sector Indepth, March 2015. 
Moody's, 2016. Change in insolvency legislation drives German and Italian bank rating actions. Sector In-depth, January 2016.

Navaretti, B., G., Calzolari, G. \& Pozzolo, A. 2016. Bail-in, up to a point. European Economy. Banks regulation and the Real Sector 2, pp. 9-32.

Ongena, S., Popov, A.A. \& Van Horen, N. 2016. The invisible hand of the government: Moral suasion during the European sovereign debt crisis. ECB Working Paper No. 1937.

Philippon, T. \& Salord, A. 2017. Bail-ins and bank resolution in Europe: A progress report. International Center for Monetary and Banking Studies, Special Report 4.

Schäfer, A., Schnabel, I. \& di Mauro, B.W. 2016. Financial sector reform after the Subprime crisis: Has anything happened? Review of Finance 20, pp. 77-125.

Sclip, A., Girardone, C. \& Miani, S. 2019. Large EU banks' capital and liquidity: Relationship and impact on credit default swap spreads, British Accounting Review 51, pp. 438-461.

Visco, I. 2016. Banks' sovereign exposures and the feedback loop between banks and their sovereigns. Concluding Remarks by Ignazio Visco at Euro50 Group "The Future of European Government Bonds Markets", 2 May 2016, Rome.

Zaghini, A. 2016. Fragmentation and heterogeneity in the euro-area corporate bond market: Back to normal? Journal of Financial Stability 23, pp. 51-61. 
Table 1 - Descriptive statistics for the CDS price series

\begin{tabular}{|c|c|c|c|c|c|c|c|c|}
\hline \multicolumn{9}{|c|}{ Panel A - Full sample period (July 2011 - June 2018) } \\
\hline & Obs. & Min & Max & Mean & Median & 5th Pct & 95th Pct & Std.Dev. \\
\hline \multicolumn{9}{|c|}{ Tovereigns } \\
\hline Austria & 1826 & 6.47 & 159.23 & 31.39 & 18.09 & 7.54 & 116.88 & 34.18 \\
\hline Belgium & 1826 & 8.37 & 341.98 & 54.60 & 31.87 & 9.28 & 215.28 & 64.82 \\
\hline Germany & 1826 & 5.00 & 79.29 & 16.93 & 12.12 & 5.09 & 56.89 & 15.00 \\
\hline Spain & 1826 & 17.71 & 492.07 & 132.82 & 74.34 & 25.54 & 373.68 & 113.79 \\
\hline Finland & 1826 & 9.64 & 87.24 & 29.68 & 23.51 & 10.86 & 75.57 & 18.25 \\
\hline France & 1826 & 7.15 & 171.56 & 40.79 & 27.86 & 7.92 & 128.58 & 35.85 \\
\hline Ireland & 1826 & 11.43 & 1191.16 & 154.57 & 47.25 & 14.50 & 688.88 & 223.34 \\
\hline Italy & 1826 & 42.04 & 498.66 & 160.45 & 110.02 & 57.78 & 411.17 & 108.20 \\
\hline Netherlands & 1826 & 8.66 & 133.84 & 38.68 & 25.49 & 10.16 & 112.02 & 30.73 \\
\hline Portugal & 1826 & 38.29 & 1521.45 & 340.46 & 208.67 & 49.24 & 1103.81 & 328.28 \\
\hline Sweden & 1826 & 5.64 & 75.71 & 17.58 & 12.04 & 6.61 & 53.34 & 14.35 \\
\hline United Kingdom & 1826 & 10.76 & 94.99 & 32.10 & 26.42 & 13.24 & 75.19 & 18.26 \\
\hline \multicolumn{9}{|c|}{ Banks } \\
\hline Austria & 1826 & 73.61 & 403.51 & 165.65 & 146.51 & 98.65 & 310.23 & 60.50 \\
\hline Belgium & 1826 & 21.22 & 391.67 & 111.90 & 71.45 & 24.39 & 275.60 & 84.52 \\
\hline Germany & 1826 & 54.25 & 358.38 & 131.62 & 107.50 & 65.46 & 272.15 & 63.65 \\
\hline Spain & 1826 & 51.56 & 741.07 & 239.07 & 135.15 & 94.62 & 654.22 & 186.33 \\
\hline \multicolumn{9}{|l|}{ Finland } \\
\hline France & 1826 & 27.55 & 361.39 & 114.87 & 76.83 & 31.60 & 282.32 & 78.80 \\
\hline Ireland & 1826 & 35.27 & 2298.98 & 346.52 & 170.71 & 36.11 & 1211.86 & 396.92 \\
\hline Italy & 1826 & 111.50 & 662.25 & 253.58 & 203.99 & 122.21 & 543.57 & 131.51 \\
\hline Netherlands & 1826 & 104.20 & 297.58 & 156.64 & 138.36 & 107.27 & 255.21 & 46.83 \\
\hline Portugal & 1826 & 88.81 & 1875.50 & 526.53 & 427.64 & 102.03 & 1509.13 & 381.04 \\
\hline Sweden & 1826 & 19.30 & 218.60 & 73.40 & 61.32 & 21.85 & 166.55 & 42.91 \\
\hline United Kingdom & 1826 & 41.85 & 309.98 & 107.86 & 83.96 & 44.83 & 252.02 & 63.90 \\
\hline \multicolumn{9}{|c|}{ Non-financial corporates } \\
\hline Austria & 1826 & 26.58 & 197.76 & 88.35 & 69.59 & 30.67 & 161.84 & 43.38 \\
\hline Belgium & 1826 & 39.63 & 251.21 & 90.23 & 77.94 & 44.63 & 179.58 & 42.00 \\
\hline Germany & 1826 & 44.83 & 363.02 & 116.80 & 90.41 & 50.51 & 286.42 & 67.97 \\
\hline Spain & 1826 & 63.52 & 557.07 & 165.72 & 119.07 & 70.43 & 397.80 & 106.76 \\
\hline Finland & 1826 & 71.36 & 427.78 & 176.72 & 128.96 & 78.41 & 368.69 & 100.40 \\
\hline France & 1826 & 64.64 & 326.62 & 138.20 & 109.29 & 71.15 & 278.07 & 66.89 \\
\hline \multicolumn{9}{|l|}{ Ireland } \\
\hline Italy & 1826 & 91.58 & 632.95 & 255.76 & 203.40 & 112.74 & 530.68 & 126.41 \\
\hline Netherlands & 1826 & 53.46 & 239.27 & 109.52 & 90.54 & 60.46 & 201.51 & 44.72 \\
\hline \multicolumn{9}{|l|}{ Portugal } \\
\hline Sweden & 1826 & 79.75 & 202.05 & 111.15 & 105.04 & 84.71 & 169.64 & 23.93 \\
\hline United Kingdom & 1826 & 82.75 & 203.30 & 115.35 & 109.14 & 86.82 & 169.53 & 24.49 \\
\hline
\end{tabular}


Table 1-Continued

\begin{tabular}{|c|c|c|c|c|c|c|c|c|}
\hline \multicolumn{9}{|c|}{ Panel B - Pre-BRRD period (July 2011 - Dec. 2014) } \\
\hline & Obs. & Min & Max & Mean & Median & 5th Pct & 95th Pct & Std.Dev. \\
\hline \multicolumn{9}{|c|}{ Sovereigns } \\
\hline Austria & 914 & 12.18 & 159.23 & 48.52 & 24.15 & 14.02 & 126.37 & 41.58 \\
\hline Belgium & 914 & 21.53 & 341.98 & 86.81 & 40.28 & 25.06 & 253.35 & 78.91 \\
\hline Germany & 914 & 7.77 & 79.29 & 25.30 & 16.33 & 9.75 & 62.44 & 17.35 \\
\hline Spain & 914 & 45.42 & 492.07 & 210.73 & 212.21 & 54.73 & 410.95 & 115.27 \\
\hline Finland & 914 & 18.55 & 87.24 & 39.56 & 28.78 & 20.28 & 79.20 & 21.11 \\
\hline France & 914 & 21.03 & 171.56 & 62.68 & 41.67 & 26.67 & 142.54 & 39.40 \\
\hline Ireland & 914 & 35.72 & 1191.16 & 275.31 & 133.99 & 40.19 & 791.98 & 265.18 \\
\hline Italy & 914 & 69.25 & 498.66 & 230.07 & 211.37 & 83.89 & 442.63 & 114.85 \\
\hline Netherlands & 914 & 18.33 & 133.84 & 59.48 & 51.46 & 21.52 & 119.24 & 31.48 \\
\hline Portugal & 914 & 129.40 & 1521.45 & 533.39 & 384.13 & 145.40 & 1179.82 & 369.91 \\
\hline Sweden & 914 & 7.65 & 75.71 & 24.33 & 15.75 & 8.18 & 58.04 & 17.62 \\
\hline United Kingdom & 914 & 16.91 & 94.99 & 41.69 & 37.67 & 18.65 & 82.50 & 20.50 \\
\hline \multicolumn{9}{|c|}{ Banks } \\
\hline Austria & 914 & 114.49 & 403.51 & 199.55 & 172.10 & 131.16 & 345.94 & 67.48 \\
\hline Belgium & 914 & 55.53 & 391.67 & 170.71 & 139.27 & 70.27 & 332.49 & 83.83 \\
\hline Germany & 914 & 84.18 & 358.38 & 172.28 & 150.01 & 87.99 & 303.05 & 67.03 \\
\hline Spain & 914 & 87.81 & 741.07 & 357.36 & 338.24 & 98.93 & 666.08 & 201.99 \\
\hline \multicolumn{9}{|l|}{ Finland } \\
\hline France & 914 & 56.79 & 361.39 & 168.33 & 160.01 & 62.49 & 300.97 & 79.47 \\
\hline Ireland & 914 & 145.06 & 2298.98 & 567.08 & 378.95 & 157.88 & 1442.72 & 462.87 \\
\hline Italy & 914 & 116.81 & 662.25 & 335.57 & 357.95 & 131.04 & 561.37 & 139.61 \\
\hline Netherlands & 914 & 109.92 & 297.58 & 188.06 & 186.39 & 121.24 & 268.45 & 47.05 \\
\hline Portugal & 914 & 156.12 & 1875.50 & 681.15 & 516.52 & 206.13 & 1578.89 & 444.57 \\
\hline Sweden & 914 & 45.30 & 218.60 & 99.95 & 85.95 & 47.15 & 180.84 & 44.19 \\
\hline United Kingdom & 914 & 50.78 & 309.98 & 148.09 & 131.63 & 60.64 & 262.78 & 67.50 \\
\hline \multicolumn{9}{|c|}{ Non-financial corporates } \\
\hline Austria & 914 & 59.67 & 197.76 & 122.98 & 127.54 & 64.14 & 170.77 & 33.55 \\
\hline Belgium & 914 & 49.29 & 251.21 & 112.58 & 111.62 & 57.71 & 204.45 & 43.67 \\
\hline Germany & 914 & 70.37 & 363.02 & 159.76 & 143.74 & 78.01 & 303.17 & 72.16 \\
\hline Spain & 914 & 73.01 & 557.07 & 233.81 & 225.58 & 84.80 & 438.46 & 113.28 \\
\hline Finland & 914 & 97.73 & 427.78 & 253.60 & 265.88 & 129.71 & 381.35 & 89.52 \\
\hline France & 914 & 80.39 & 326.62 & 181.74 & 178.10 & 87.81 & 290.85 & 68.35 \\
\hline \multicolumn{9}{|l|}{ Ireland } \\
\hline Italy & 914 & 156.83 & 632.95 & 346.59 & 339.09 & 179.11 & 574.69 & 117.51 \\
\hline Netherlands & 914 & 79.68 & 239.27 & 143.21 & 146.22 & 85.20 & 209.08 & 39.70 \\
\hline \multicolumn{9}{|l|}{ Portugal } \\
\hline Sweden & 914 & 79.75 & 202.05 & 117.67 & 107.29 & 83.71 & 179.44 & 29.68 \\
\hline United Kingdom & 914 & 91.84 & 203.30 & 128.17 & 123.63 & 94.63 & 177.38 & 26.45 \\
\hline
\end{tabular}


Table 1 - Continued

\begin{tabular}{|c|c|c|c|c|c|c|c|c|}
\hline \multicolumn{9}{|c|}{ Panel C - Post-BRRD period (Jan. 2015 - June 2018) } \\
\hline & Obs. & Min & Max & Mean & Median & 5th Pct & 95th Pct & Std.Dev. \\
\hline \multicolumn{9}{|c|}{ Sovereigns } \\
\hline Austria & 912 & 6.47 & 23.04 & 14.22 & 15.92 & 7.27 & 19.50 & 4.30 \\
\hline Belgium & 912 & 8.37 & 45.96 & 22.32 & 23.26 & 8.91 & 35.82 & 9.63 \\
\hline Germany & 912 & 5.00 & 15.56 & 8.54 & 7.77 & 5.09 & 13.50 & 2.88 \\
\hline Spain & 912 & 17.71 & 105.03 & 54.74 & 59.52 & 21.02 & 83.03 & 20.76 \\
\hline Finland & 912 & 9.64 & 29.95 & 19.78 & 21.02 & 10.14 & 25.98 & 4.93 \\
\hline France & 912 & 7.15 & 37.73 & 18.85 & 19.92 & 7.72 & 31.26 & 7.57 \\
\hline Ireland & 912 & 11.43 & 70.23 & 33.56 & 37.32 & 11.70 & 51.32 & 12.90 \\
\hline Italy & 912 & 42.04 & 140.50 & 90.67 & 92.33 & 51.28 & 125.88 & 22.32 \\
\hline Netherlands & 912 & 8.66 & 31.94 & 17.84 & 16.43 & 9.43 & 26.48 & 5.50 \\
\hline Portugal & 912 & 38.29 & 286.38 & 147.11 & 142.94 & 44.39 & 237.61 & 63.09 \\
\hline Sweden & 912 & 5.64 & 20.30 & 10.81 & 10.07 & 6.29 & 16.25 & 3.12 \\
\hline United Kingdom & 912 & 10.76 & 46.38 & 22.49 & 20.84 & 12.38 & 36.60 & 7.86 \\
\hline \multicolumn{9}{|c|}{ Banks } \\
\hline Austria & 912 & 73.61 & 173.69 & 131.69 & 141.04 & 95.00 & 158.66 & 21.47 \\
\hline Belgium & 912 & 21.22 & 93.27 & 52.96 & 60.00 & 22.71 & 73.73 & 17.93 \\
\hline Germany & 912 & 54.25 & 126.90 & 90.87 & 94.53 & 58.72 & 113.44 & 17.08 \\
\hline Spain & 912 & 51.56 & 190.33 & 120.52 & 122.93 & 89.24 & 156.80 & 23.58 \\
\hline \multicolumn{9}{|l|}{ Finland } \\
\hline France & 912 & 27.55 & 117.54 & 61.29 & 68.57 & 29.09 & 84.71 & 19.20 \\
\hline Ireland & 912 & 35.27 & 199.62 & 125.49 & 147.87 & 35.30 & 186.93 & 56.31 \\
\hline Italy & 912 & 111.50 & 291.87 & 171.42 & 159.97 & 118.22 & 240.74 & 40.16 \\
\hline Netherlands & 912 & 104.20 & 160.67 & 125.15 & 127.12 & 105.06 & 145.30 & 13.85 \\
\hline Portugal & 912 & 88.81 & 829.09 & 371.58 & 307.22 & 94.77 & 767.04 & 211.59 \\
\hline Sweden & 912 & 19.30 & 92.74 & 46.80 & 50.98 & 20.69 & 73.79 & 17.78 \\
\hline United Kingdom & 912 & 41.85 & 121.33 & 67.55 & 65.74 & 43.57 & 103.52 & 19.07 \\
\hline \multicolumn{9}{|c|}{ Non-financial corporates } \\
\hline Austria & 912 & 26.58 & 96.08 & 53.65 & 56.13 & 28.62 & 74.06 & 15.29 \\
\hline Belgium & 912 & 39.63 & 186.32 & 67.83 & 64.30 & 43.21 & 110.70 & 24.88 \\
\hline Germany & 912 & 44.83 & 138.00 & 73.73 & 73.14 & 48.87 & 105.80 & 18.11 \\
\hline Spain & 912 & 63.52 & 198.27 & 97.47 & 95.83 & 68.46 & 139.99 & 25.67 \\
\hline Finland & 912 & 71.36 & 172.09 & 99.66 & 98.49 & 75.15 & 127.38 & 16.88 \\
\hline France & 912 & 64.64 & 175.09 & 94.58 & 94.20 & 69.51 & 134.01 & 21.79 \\
\hline \multicolumn{9}{|l|}{ Ireland } \\
\hline Italy & 912 & 91.58 & 290.82 & 164.73 & 165.98 & 107.92 & 231.63 & 40.02 \\
\hline Netherlands & 912 & 53.46 & 112.03 & 75.76 & 76.54 & 57.39 & 95.47 & 12.13 \\
\hline \multicolumn{9}{|l|}{ Portugal } \\
\hline Sweden & 912 & 80.78 & 153.11 & 104.61 & 103.01 & 85.27 & 126.77 & 13.39 \\
\hline United Kingdom & 912 & 82.75 & 143.44 & 102.50 & 99.95 & 85.37 & 126.03 & 13.04 \\
\hline
\end{tabular}

Description: The table reports the descriptive statistics (expressed in bps) for sovereign CDS, bank CDS and non-financial corporate CDS (daily data). For each group, the following metrics are reported: the number of observations (Obs.), the minimum (Min), the maximum (Max), the mean (Mean), the median (Median), the 5th and 95th percentiles (5th Pct and 95th Pct, respectively) and the standard deviation (Std.Dev.). Panel A provides the statistics for the full sample period (July 2011 - June 2018), Panel B for the pre-BRRD period (July 2011 - Dec. 2014) and Panel C for the post-BRRD period (Jan. 2015 - June 2018).

Note: CDS data for Finnish banks, and Irish and Portuguese non-financial firms, were either not available or incomplete. 
Table 2 - The impact of BRRD on the sovereign-bank nexus for all the selected EU-countries

\begin{tabular}{|c|c|c|c|c|c|c|c|c|}
\hline \multicolumn{9}{|c|}{ Panel A: Preferred model specification - 01/01/15 intervention date - daily data } \\
\hline & $(1)$ & $(2)$ & (3) & (4) & (5) & (6) & (7) & (8) \\
\hline \multirow[t]{2}{*}{ BRRD } & $-19.545^{* * *}$ & $-19.921 * * *$ & $-19.536^{* * *}$ & $-19.924 * * *$ & $-19.545^{* * *}$ & $-19.932 * * *$ & $-19.564^{* * *}$ & $-19.952 * * *$ \\
\hline & $(7.155)$ & (7.153) & (7.155) & (7.153) & (7.156) & (7.153) & (7.157) & (7.155) \\
\hline \multirow[t]{2}{*}{ BRRD $x$ Treat } & $-19.861^{*}$ & $-18.333^{*}$ & $-19.951^{*}$ & $-18.388^{*}$ & $-19.949 *$ & $-18.386^{*}$ & $-19.951^{*}$ & $-18.388^{*}$ \\
\hline & (10.690) & (10.705) & (10.690) & (10.705) & (10.690) & (10.705) & (10.690) & (10.705) \\
\hline \multirow[t]{2}{*}{ Crisis } & $48.326^{* * *}$ & $53.379 * * *$ & $49.044 * * *$ & $54.431^{* * *}$ & $49.086 * * *$ & $54.478^{* * *}$ & $48.990 * * *$ & $54.377^{* * *}$ \\
\hline & (6.993) & (7.283) & (7.029) & (7.336) & (7.033) & (7.341) & (7.025) & (7.332) \\
\hline \multirow[t]{2}{*}{ Treat } & & 10.275 & & 10.162 & & 10.160 & & 10.162 \\
\hline & & (12.995) & & $(13.003)$ & & $(13.003)$ & & $(13.003)$ \\
\hline \multirow[t]{2}{*}{ ITRAXX } & & & $-0.185^{* * *}$ & $-0.188^{* * *}$ & & & & \\
\hline & & & $(0.028)$ & $(0.029)$ & & & & \\
\hline \multirow[t]{2}{*}{ STOXX600 } & & & & & $0.693 * * *$ & $0.724^{* * *}$ & & \\
\hline & & & & & $(0.089)$ & $(0.092)$ & & \\
\hline \multirow[t]{2}{*}{ VSTOXX } & & & & & & & $-0.094 * * *$ & $-0.093 * * *$ \\
\hline & & & & & & & $(0.010)$ & $(0.010)$ \\
\hline \multirow[t]{2}{*}{ Constant } & $99.328 * * *$ & $95.542 * * *$ & $99.430 * * *$ & $95.633^{* * *}$ & $99.427^{* * *}$ & $95.630 * * *$ & $99.474 * * *$ & $95.677^{* * *}$ \\
\hline & $(2.352)$ & $(8.623)$ & $(2.353)$ & (8.625) & (2.354) & (8.625) & $(2.355)$ & (8.628) \\
\hline Obs. & 334,144 & 334,144 & 333,568 & 333,568 & 333,568 & 333,568 & 333,568 & 333,568 \\
\hline R-squared & 0.631 & 0.089 & 0.632 & 0.090 & 0.632 & 0.090 & 0.632 & 0.090 \\
\hline Firm FE & YES & NO & YES & NO & YES & NO & YES & NO \\
\hline Country FE & NO & YES & NO & YES & NO & YES & NO & YES \\
\hline \multicolumn{9}{|c|}{ Panel B: Preferred model specification - 14/05/14 intervention date - daily data } \\
\hline & $(1)$ & $(2)$ & (3) & (4) & $(5)$ & (6) & (7) & (8) \\
\hline BRRD & $\begin{array}{l}-29.108^{* * *} \\
(7.780)\end{array}$ & $\begin{array}{c}29.584^{* * *} \\
(7.787)\end{array}$ & $\begin{array}{l}-29.103^{* * *} \\
(7.780)\end{array}$ & $\begin{array}{l}-29.597^{* * *} \\
(7.788)\end{array}$ & $\begin{array}{l}-29.102^{* * *} \\
(7.780)\end{array}$ & $\begin{array}{l}-29.595^{* * *} \\
(7.789)\end{array}$ & $\begin{array}{l}-29.115^{* * *} \\
(7.782)\end{array}$ & $\begin{array}{l}-29.610^{* * *} \\
(7.790)\end{array}$ \\
\hline BRRD $\times$ Treat & $\begin{array}{l}-27.613^{* *} \\
(11.814)\end{array}$ & $\begin{array}{l}-25.222^{* *} \\
(11.876)\end{array}$ & $\begin{array}{l}-27.672^{* *} \\
(11.813)\end{array}$ & $\begin{array}{l}-25.201 * * \\
(11.877)\end{array}$ & $\begin{array}{l}-27.669 * * \\
(11.814)\end{array}$ & $\begin{array}{l}-25.198 * * \\
(11.878)\end{array}$ & $\begin{array}{l}-27.672^{* *} \\
(11.813)\end{array}$ & $\begin{array}{l}-25.201^{* *} \\
(11.877)\end{array}$ \\
\hline Crisis & $\begin{array}{l}37.133^{* * *} \\
(6.403)\end{array}$ & $\begin{array}{l}42.319 * * * \\
(6.687)\end{array}$ & $\begin{array}{l}37.842^{* * *} \\
(6.438)\end{array}$ & $\begin{array}{l}43.368^{* * *} \\
(6.738)\end{array}$ & $\begin{array}{l}37.890 * * * \\
(6.442)\end{array}$ & $\begin{array}{l}43.420^{* * *} \\
(6.743)\end{array}$ & $\begin{array}{l}37.805^{* * *} \\
(6.436)\end{array}$ & $\begin{array}{l}43.330 * * * \\
(6.736)\end{array}$ \\
\hline Treat & & $\begin{array}{l}16.000 \\
(14.334)\end{array}$ & & $\begin{array}{l}15.844 \\
(14.343)\end{array}$ & & $\begin{array}{l}15.842 \\
(14.343)\end{array}$ & & $\begin{array}{l}15.844 \\
(14.343)\end{array}$ \\
\hline ITRAXX & & & $\begin{array}{l}-0.138^{* * *} \\
(0.026)\end{array}$ & $\begin{array}{l}-0.141^{* * *} \\
(0.026)\end{array}$ & & & & \\
\hline STOXX600 & & & & & $\begin{array}{l}0.597 * * * \\
(0.082)\end{array}$ & $\begin{array}{l}0.630 * * * \\
(0.085)\end{array}$ & & \\
\hline VSTOXX & & & & & & & $\begin{array}{l}-0.067^{* * *} \\
(0.008)\end{array}$ & $\begin{array}{l}-0.066 * * * \\
(0.008)\end{array}$ \\
\hline Constant & $\begin{array}{l}110.409 * * * \\
(3.066)\end{array}$ & $\begin{array}{l}104.852^{* * *} \\
(9.736)\end{array}$ & $\begin{array}{l}110.507^{* * *} \\
(3.068)\end{array}$ & $\begin{array}{l}104.947^{* * *} \\
(9.740)\end{array}$ & $\begin{array}{l}110.498^{* * *} \\
(3.068)\end{array}$ & $\begin{array}{l}104.938^{* * *} \\
(9.740)\end{array}$ & $\begin{array}{l}110.535^{* * *} \\
(3.070)\end{array}$ & $\begin{array}{l}104.976^{* * *} \\
(9.743)\end{array}$ \\
\hline Obs. & 334,144 & 334,144 & 333,568 & 333,568 & 333,568 & 333,568 & 333,568 & 333,568 \\
\hline R-squared & 0.642 & 0.099 & 0.642 & 0.100 & 0.642 & 0.100 & 0.642 & 0.100 \\
\hline Firm FE & YES & NO & YES & NO & YES & NO & YES & NO \\
\hline Country FE & NO & YES & NO & YES & NO & YES & NO & YES \\
\hline
\end{tabular}


Table 2 - Continued

\begin{tabular}{|c|c|c|c|c|c|c|c|c|}
\hline \multicolumn{9}{|c|}{ Panel C: Preferred model specification - 01/01/15 intervention date - weekly data } \\
\hline & $(1)$ & $(2)$ & (3) & $(4)$ & $(5)$ & (6) & (7) & (8) \\
\hline \multirow[t]{2}{*}{ BRRD } & $-19.554 * * *$ & $-19.904 * * *$ & $-19.546 * * *$ & $-19.910 * * *$ & $-19.534 * * *$ & $-19.896 * * *$ & $-19.598 * * *$ & $-19.965 * * *$ \\
\hline & (7.148) & (7.147) & (7.138) & (7.136) & $(7.142)$ & (7.141) & (7.151) & (7.149) \\
\hline \multirow[t]{2}{*}{ BRRD $x$ Treat } & $-19.676^{*}$ & $-18.216^{*}$ & $-19.754 *$ & $-18.216^{*}$ & $-19.742^{*}$ & $-18.205^{*}$ & $-19.753 *$ & $-18.215^{*}$ \\
\hline & (10.692) & $(10.712)$ & $(10.701)$ & (10.718) & (10.702) & (10.719) & $(10.701)$ & (10.718) \\
\hline \multirow[t]{2}{*}{ Crisis } & $45.941 * * *$ & $50.076 * * *$ & $47.066 * * *$ & $51.728 * * *$ & $47.351 * * *$ & $52.031 * * *$ & $46.991 * * *$ & $51.646 * * *$ \\
\hline & (6.851) & (7.091) & (6.913) & (7.182) & (6.936) & (7.208) & (6.901) & (7.169) \\
\hline \multirow[t]{2}{*}{ Treat } & & 10.610 & & 10.338 & & 10.330 & & 10.337 \\
\hline & & (12.976) & & (12.995) & & (12.996) & & (12.996) \\
\hline \multirow[t]{2}{*}{ ITRAXX } & & & $-0.086 * * *$ & $-0.088 * *$ & & & & \\
\hline & & & (0.033) & (0.034) & & & & \\
\hline \multirow[t]{2}{*}{ STOXX600 } & & & & & $0.571 * * *$ & $0.602 * * *$ & & \\
\hline & & & & & (0.100) & (0.104) & & \\
\hline \multirow[t]{2}{*}{ VstoxX } & & & & & & & $-0.097 * * *$ & $-0.094 * * *$ \\
\hline & & & & & & & $(0.013)$ & (0.014) \\
\hline \multirow[t]{2}{*}{ Constant } & $99.047 * * *$ & $95.276 * * *$ & $99.195^{* * *}$ & $95.424 * * *$ & $99.140 * * *$ & $95.367^{* * *}$ & $99.294 * * *$ & $95.524 * * *$ \\
\hline & (2.349) & (8.616) & (2.341) & (8.615) & $(2.342)$ & (8.611) & (2.352) & (8.625) \\
\hline Obs. & 67,095 & 67,095 & 66,910 & 66,910 & 66,910 & 66,910 & 66,910 & 66,910 \\
\hline R-squared & 0.632 & 0.085 & 0.633 & 0.087 & 0.633 & 0.087 & 0.633 & 0.087 \\
\hline Firm FE & YES & NO & YES & NO & YES & NO & YES & NO \\
\hline Country FE & NO & YES & NO & YES & NO & YES & NO & YES \\
\hline \multicolumn{9}{|c|}{ Panel D: Preferred model specification - 14/05/14 intervention date - weekly data } \\
\hline & (1) & (2) & (3) & (4) & (5) & (6) & (7) & (8) \\
\hline BRRD & $\begin{array}{c}-34.652^{* * *} \\
(8.450)\end{array}$ & $\begin{array}{c}-35.170^{* * *} \\
(8.462)\end{array}$ & $\begin{array}{c}-34.749 * * * \\
(8.444)\end{array}$ & $\begin{array}{c}-35.309 * * * \\
(8.458)\end{array}$ & $\begin{array}{c}-34.649 * * * \\
(8.444)\end{array}$ & $\begin{array}{c}-35.204^{* * *} \\
(8.458)\end{array}$ & $\begin{array}{c}-34.690 * * * \\
(8.455)\end{array}$ & $\begin{array}{c}-35.256^{* * *} \\
(8.469)\end{array}$ \\
\hline \multirow{2}{*}{$\begin{array}{l}\text { BRRD } x \\
\text { Treat }\end{array}$} & $-31.551^{* *}$ & $-29.142^{* *}$ & $-31.588^{* *}$ & $-29.025^{* *}$ & $-31.571^{* *}$ & $-29.008^{* *}$ & $-31.585^{* *}$ & $-29.022^{* *}$ \\
\hline & $(12.720)$ & $(12.792)$ & $(12.737)$ & $(12.815)$ & (12.739) & $(12.817)$ & $(12.737)$ & $(12.815)$ \\
\hline \multirow[t]{2}{*}{ Crisis } & $27.138^{* * *}$ & $31.397^{* * *}$ & $28.067^{* * *}$ & $32.852^{* * *}$ & $28.460 * * *$ & $33.266^{* * *}$ & $28.157^{* * *}$ & $32.932 * * *$ \\
\hline & $(5.900)$ & (6.137) & $(5.945)$ & $(6.207)$ & (5.970) & $(6.235)$ & (5.944) & (6.205) \\
\hline \multirow[t]{2}{*}{ Treat } & & 20.242 & & 19.895 & & 19.883 & & 19.893 \\
\hline & & (15.292) & & (15.324) & & (15.325) & & (15.324) \\
\hline \multirow[t]{2}{*}{ ITRAXX } & & & 0.002 & -0.001 & & & & \\
\hline & & & $(0.031)$ & $(0.032)$ & & & & \\
\hline \multirow[t]{2}{*}{ STOXX600 } & & & & & $0.454 * * *$ & $0.485 * * *$ & & \\
\hline & & & & & $(0.094)$ & (0.099) & & \\
\hline \multirow[t]{2}{*}{ VSTOXX } & & & & & & & $-0.058 * * *$ & $-0.055^{* * *}$ \\
\hline & & & & & & & $(0.011)$ & $(0.012)$ \\
\hline \multirow[t]{2}{*}{ Constant } & $117.678^{* * *}$ & $111.015^{* * *}$ & $117.917^{* * *}$ & $111.280^{* * *}$ & $117.784^{* * *}$ & $111.144 * * *$ & $117.900 * * *$ & $111.266^{* * *}$ \\
\hline & (3.758) & $(10.626)$ & (3.751) & (10.633) & (3.749) & $(10.625)$ & $(3.764)$ & $(10.640)$ \\
\hline Obs. & 67,095 & 67,095 & 66,910 & 66,910 & 66,910 & 66,910 & 66,910 & 66,910 \\
\hline R-squared & 0.647 & 0.100 & 0.648 & 0.102 & 0.648 & 0.102 & 0.648 & 0.102 \\
\hline Firm FE & YES & NO & YES & NO & YES & NO & YES & NO \\
\hline Country FE & NO & YES & NO & YES & NO & YES & NO & YES \\
\hline
\end{tabular}

Description: The table reports the results for the preferred DiD estimation applied on the 12 selected EU-countries together. The dependent variable is the GAP (i.e. difference between non-sovereign CDS and sovereign CDS spreads) calculated on both daily (Panels $A$ and $B$ ) and weekly data (Panels $C$ and $D$ ) and expressed in bps. Two alternative intervention dates are employed. Firm and country fixed effects are included alternatively. Robust standard errors, clustered at firm level, are reported in parentheses.

Note: The crisis dummy takes the value one from $1^{\text {st }}$ July 2011 to $1^{\text {st }}$ September 2012, zero otherwise.

*** significant at the $1 \%$ level; ** significant at the $5 \%$ level; * significant at the $10 \%$ level. 
Table 3 - The impact of BRRD on the sovereign-bank nexus: Euro area core countries

\begin{tabular}{|c|c|c|c|c|c|c|c|c|}
\hline \multicolumn{9}{|c|}{ Panel A: Preferred model specification - Euro area core countries } \\
\hline & $(1)$ & $(2)$ & $(3)$ & $(4)$ & $(5)$ & $(6)$ & (7) & $(8)$ \\
\hline BRRD & $\begin{array}{c}-39.273^{* * *} \\
(11.393)\end{array}$ & $\begin{array}{c}-39.861^{* * *} \\
(11.392)\end{array}$ & $\begin{array}{c}-39.290^{* * *} \\
(11.392)\end{array}$ & $\begin{array}{c}-39.911^{* * *} \\
(11.390)\end{array}$ & $\begin{array}{c}-39.299 * * * \\
(11.393)\end{array}$ & $\begin{array}{c}-39.919 * * * \\
(11.392)\end{array}$ & $\begin{array}{c}-39.323^{* * *} \\
(11.396)\end{array}$ & $\begin{array}{c}-39.944 * * * \\
(11.395)\end{array}$ \\
\hline BRRD $\times$ Treat & $\begin{array}{c}5.476 \\
(15.883)\end{array}$ & $\begin{array}{c}7.635 \\
(15.967)\end{array}$ & $\begin{array}{c}5.648 \\
(15.888)\end{array}$ & $\begin{array}{c}7.911 \\
(15.977)\end{array}$ & $\begin{array}{c}5.652 \\
(15.889)\end{array}$ & $\begin{array}{c}7.915 \\
(15.977)\end{array}$ & $\begin{array}{c}5.647 \\
(15.888)\end{array}$ & $\begin{array}{c}7.910 \\
(15.977)\end{array}$ \\
\hline Crisis & $\begin{array}{c}58.843^{* * *} \\
(10.864)\end{array}$ & $\begin{array}{c}63.763^{* * *} \\
(11.517)\end{array}$ & $\begin{array}{c}59.538^{* * *} \\
(10.913)\end{array}$ & $\begin{array}{c}64.707^{* * *} \\
(11.598)\end{array}$ & $\begin{array}{c}59.600 * * * \\
(10.920)\end{array}$ & $\begin{array}{c}64.774 * * * \\
(11.606)\end{array}$ & $\begin{array}{c}59.475^{* * *} \\
(10.907)\end{array}$ & $\begin{array}{c}64.643^{* * *} \\
(11.591)\end{array}$ \\
\hline Treat & & $\begin{array}{c}6.259 \\
(20.281)\end{array}$ & & $\begin{array}{c}5.971 \\
(20.301)\end{array}$ & & $\begin{array}{c}5.968 \\
(20.301)\end{array}$ & & $\begin{array}{c}5.972 \\
(20.301)\end{array}$ \\
\hline ITRAXX & & & $\begin{array}{c}-0.220^{* * *} \\
(0.042)\end{array}$ & $\begin{array}{c}-0.224^{* * *} \\
(0.043)\end{array}$ & & & & \\
\hline STOXX600 & & & & & $\begin{array}{c}0.885^{* * *} \\
(0.147)\end{array}$ & $\begin{array}{c}0.931 * * * \\
(0.152)\end{array}$ & & \\
\hline VSTOXX & & & & & & & $\begin{array}{c}-0.118^{* * *} \\
(0.015)\end{array}$ & $\begin{array}{c}-0.117^{* * *} \\
(0.015)\end{array}$ \\
\hline Constant & $\begin{array}{c}109.146^{* * *} \\
(3.801)\end{array}$ & $\begin{array}{c}106.923 * * * \\
(12.421)\end{array}$ & $\begin{array}{c}109.169 * * * \\
(3.800)\end{array}$ & $\begin{array}{c}106.985^{* * *} \\
(12.423)\end{array}$ & $\begin{array}{c}109.164^{* * *} \\
(3.801)\end{array}$ & $\begin{array}{c}106.979 * * * \\
(12.422)\end{array}$ & $\begin{array}{c}109.223^{* * *} \\
(3.805)\end{array}$ & $\begin{array}{c}107.039 * * * \\
(12.428)\end{array}$ \\
\hline Obs. & 174,064 & 174,064 & 173,904 & 173,904 & 173,904 & 173,904 & 173,904 & 173,904 \\
\hline R-squared & 0.596 & 0.109 & 0.596 & 0.111 & 0.596 & 0.111 & 0.596 & 0.111 \\
\hline Firm FE & YES & NO & YES & NO & YES & NO & YES & NO \\
\hline Country FE & NO & YES & NO & YES & NO & YES & NO & YES \\
\hline \multicolumn{9}{|c|}{ Panel B: Preferred model specification - Large euro area core countries } \\
\hline & (1) & (2) & (3) & (4) & (5) & (6) & (7) & (8) \\
\hline BRRD & $\begin{array}{c}-31.788 * * * \\
(11.857)\end{array}$ & $\begin{array}{c}-32.437^{* * *} \\
(11.858)\end{array}$ & $\begin{array}{c}-31.826^{* * *} \\
(11.857)\end{array}$ & $\begin{array}{c}-32.513^{* * *} \\
(11.858)\end{array}$ & $\begin{array}{c}-31.833 * * * \\
(11.858)\end{array}$ & $\begin{array}{c}-32.520 * * * \\
(11.860)\end{array}$ & $\begin{array}{c}-31.855^{* * *} \\
(11.862)\end{array}$ & $\begin{array}{c}-32.543^{* * *} \\
(11.863)\end{array}$ \\
\hline BRRD $x$ Treat & $\begin{array}{c}-3.460 \\
(17.057)\end{array}$ & $\begin{array}{c}-0.978 \\
(17.168)\end{array}$ & $\begin{array}{c}-3.204 \\
(17.071)\end{array}$ & $\begin{array}{c}-0.598 \\
(17.187)\end{array}$ & $\begin{array}{c}-3.200 \\
(17.071)\end{array}$ & $\begin{array}{c}-0.595 \\
(17.188)\end{array}$ & $\begin{array}{c}-3.205 \\
(17.070)\end{array}$ & $\begin{array}{c}-0.599 \\
(17.187)\end{array}$ \\
\hline Crisis & $\begin{array}{c}59.082^{* * *} \\
(11.392)\end{array}$ & $\begin{array}{c}64.583^{* * *} \\
(12.174)\end{array}$ & $\begin{array}{c}59.756^{* * *} \\
(11.444)\end{array}$ & $\begin{array}{c}65.537^{* * *} \\
(12.268)\end{array}$ & $\begin{array}{c}59.816^{* * *} \\
(11.451)\end{array}$ & $\begin{array}{c}65.602 * * * \\
(12.277)\end{array}$ & $\begin{array}{c}59.700^{* * *} \\
(11.438)\end{array}$ & $\begin{array}{c}65.479 * * * \\
(12.262)\end{array}$ \\
\hline Treat & & $\begin{array}{c}7.933 \\
(21.943)\end{array}$ & & $\begin{array}{c}7.575 \\
(21.967)\end{array}$ & & $\begin{array}{c}7.572 \\
(21.967)\end{array}$ & & $\begin{array}{c}7.576 \\
(21.967)\end{array}$ \\
\hline ITRAXX & & & $\begin{array}{c}-0.195^{* * *} \\
(0.042)\end{array}$ & $\begin{array}{c}-0.202^{* * *} \\
(0.044)\end{array}$ & & & & \\
\hline STOXX600 & & & & & $\begin{array}{c}0.813^{* * *} \\
(0.148)\end{array}$ & $\begin{array}{c}0.862^{* * *} \\
(0.155)\end{array}$ & & \\
\hline VSTOXX & & & & & & & $\begin{array}{c}-0.109 * * * \\
(0.015)\end{array}$ & $\begin{array}{c}-0.108^{* * *} \\
(0.015)\end{array}$ \\
\hline Constant & $\begin{array}{c}103.416^{* * *} \\
(4.076)\end{array}$ & $\begin{array}{c}100.791^{* * *} \\
(13.279)\end{array}$ & $\begin{array}{c}103.444 * * * \\
(4.074)\end{array}$ & $\begin{array}{c}100.866^{* * *} \\
(13.281)\end{array}$ & $\begin{array}{c}103.438^{* * *} \\
(4.075)\end{array}$ & $\begin{array}{c}100.859 * * * \\
(13.279)\end{array}$ & $\begin{array}{c}103.493^{* * *} \\
(4.079)\end{array}$ & $\begin{array}{c}100.915^{* * *} \\
(13.286)\end{array}$ \\
\hline Obs. & 150,741 & 150,741 & 150,598 & 150,598 & 150,598 & 150,598 & 150,598 & 150,598 \\
\hline R-squared & 0.617 & 0.085 & 0.618 & 0.086 & 0.618 & 0.086 & 0.618 & 0.086 \\
\hline Firm FE & YES & NO & YES & NO & YES & NO & YES & NO \\
\hline Country FE & NO & YES & NO & YES & NO & YES & NO & YES \\
\hline
\end{tabular}


Table 3 - Continued

\begin{tabular}{|c|c|c|c|c|c|c|c|c|}
\hline \multicolumn{9}{|c|}{ Panel C: Preferred model specification - Small euro area core countries } \\
\hline & (1) & $(2)$ & (3) & $(4)$ & $(5)$ & $(6)$ & (7) & (8) \\
\hline \multirow[t]{2}{*}{ BRRD } & $-93.229 * *$ & $-93.035^{* *}$ & $-93.076^{* *}$ & $-92.868^{* *}$ & $-93.099 * *$ & $-92.889 * *$ & $-93.131^{* *}$ & $-92.922 * *$ \\
\hline & (35.028) & $(35.032)$ & $(34.987)$ & $(34.991)$ & (34.991) & (34.996) & $(35.001)$ & $(35.005)$ \\
\hline \multirow[t]{2}{*}{ BRRD $\times$ Treat } & 66.194 & 65.564 & 65.890 & 65.208 & 65.908 & 65.226 & 65.885 & 65.203 \\
\hline & (44.822) & (44.804) & (44.722) & (44.704) & (44.729) & (44.711) & (44.720) & $(44.702)$ \\
\hline \multirow[t]{2}{*}{ Crisis } & 56.917 & 57.356 & 57.621 & 58.170 & 57.683 & 58.236 & 57.523 & 58.077 \\
\hline & (35.169) & (35.333) & (35.285) & (35.443) & (35.310) & (35.469) & (35.263) & $(35.421)$ \\
\hline \multirow[t]{2}{*}{ Treat } & & 6.259 & & 6.550 & & 6.535 & & 6.553 \\
\hline & & (33.654) & & (33.535) & & (33.539) & & $(33.534)$ \\
\hline \multirow[t]{2}{*}{ ITRAXX } & & & $-0.376^{* *}$ & $-0.362^{* *}$ & & & & \\
\hline & & & (0.139) & $(0.141)$ & & & & \\
\hline \multirow[t]{2}{*}{ STOXX600 } & & & & & $1.389 * *$ & $1.384^{* *}$ & & \\
\hline & & & & & (0.514) & $(0.518)$ & & \\
\hline \multirow[t]{2}{*}{ VSTOXX } & & & & & & & $-0.174^{* * *}$ & $-0.176 * * *$ \\
\hline & & & & & & & $(0.054)$ & $(0.055)$ \\
\hline \multirow[t]{2}{*}{ Constant } & $146.231^{* * *}$ & $144.230^{* * *}$ & $146.234^{* * *}$ & $144.130^{* * *}$ & $146.230^{* * *}$ & $144.128^{* * *}$ & $146.321^{* * *}$ & $144.214^{* * *}$ \\
\hline & $(9.528)$ & (31.926) & (9.523) & (31.901) & (9.523) & (31.899) & (9.539) & (31.921) \\
\hline Obs. & 23,323 & 23,323 & 23,305 & 23,305 & 23,305 & 23,305 & 23,305 & 23,305 \\
\hline R-squared & 0.497 & 0.265 & 0.498 & 0.265 & 0.498 & 0.266 & 0.498 & 0.265 \\
\hline Firm FE & YES & NO & YES & NO & YES & NO & YES & NO \\
\hline Country FE & NO & YES & NO & YES & NO & YES & NO & YES \\
\hline
\end{tabular}

Description: The table reports the results for the preferred DiD estimation on core euro area countries. Panel A includes all euro area core economies. Panel B focuses on large euro area core countries (France, Germany and Netherlands), while Panel $\mathrm{C}$ considers small euro area core countries (Austria, Belgium and Finland).

The dependent variable is the GAP variable (i.e. difference between sovereign CDS and non-sovereign CDS spreads) calculated on daily data and expressed in bps.

Firm and country fixed effects are included alternatively. Robust standard errors, clustered at firm level, are reported in parentheses.

Note: The crisis dummy takes the value one from $1^{\text {st }}$ July 2011 to $1^{\text {st }}$ September 2012, zero otherwise.

${ }^{* * *}$ significant at the $1 \%$ level; ${ }^{* *}$ significant at the $5 \%$ level; * significant at the $10 \%$ level. 
Table 4 - The impact of BRRD on the sovereign-bank nexus: Euro area peripheral countries

\begin{tabular}{|c|c|c|c|c|c|c|c|c|}
\hline \multicolumn{9}{|c|}{ Panel A: Preferred model specification - Euro area peripheral countries } \\
\hline & (1) & $(2)$ & (3) & $(4)$ & $(5)$ & $(6)$ & (7) & (8) \\
\hline \multirow[t]{2}{*}{ BRRD } & -4.327 & -4.416 & -4.684 & -4.820 & -4.734 & -4.868 & -4.771 & -4.902 \\
\hline & $(23.019)$ & $(22.408)$ & $(22.825)$ & $(22.139)$ & $(22.830)$ & $(22.144)$ & $(22.828)$ & $(22.143)$ \\
\hline \multirow[t]{2}{*}{ BRRD $\times$ Treat } & -27.518 & -27.624 & -27.424 & -27.533 & -27.423 & -27.532 & -27.414 & -27.524 \\
\hline & $(28.314)$ & $(27.720)$ & (28.159) & (27.499) & (28.158) & (27.498) & (28.154) & (27.495) \\
\hline \multirow[t]{2}{*}{ Crisis } & $83.666^{* *}$ & $89.099 * * *$ & $86.590 * *$ & $92.941 * * *$ & $86.579 * *$ & $92.930^{* * *}$ & $86.439 * *$ & $92.800 * * *$ \\
\hline & $(31.012)$ & $(30.673)$ & (31.319) & (30.939) & (31.331) & $(30.951)$ & (31.321) & $(30.940)$ \\
\hline \multirow[t]{2}{*}{ Treat } & & 40.128 & & 40.255 & & 40.253 & & 40.242 \\
\hline & & $(32.901)$ & & (32.441) & & (32.439) & & (32.434) \\
\hline \multirow[t]{2}{*}{ ITRAXX } & & & $-0.499 * * *$ & $-0.467 * * *$ & & & & \\
\hline & & & $(0.138)$ & $(0.144)$ & & & & \\
\hline \multirow[t]{2}{*}{ STOXX600 } & & & & & $1.142^{* * *}$ & $1.064^{* * *}$ & & \\
\hline & & & & & $(0.315)$ & $(0.344)$ & & \\
\hline \multirow[t]{2}{*}{ VSTOXX } & & & & & & & $-0.176 * * *$ & $-0.154 * * *$ \\
\hline & & & & & & & $(0.048)$ & $(0.052)$ \\
\hline \multirow[t]{2}{*}{ Constant } & $112.737^{* * *}$ & $78.276^{* * *}$ & $113.527^{* * *}$ & $78.862 * * *$ & $113.554^{* * *}$ & $78.890^{* * *}$ & $113.631 * * *$ & $78.969 * * *$ \\
\hline & (7.491) & (26.079) & (7.545) & $(25.624)$ & (7.548) & $(25.625)$ & (7.544) & $(25.627)$ \\
\hline Obs. & 32,735 & 32,735 & 32,469 & 32,469 & 32,469 & 32,469 & 32,469 & 32,469 \\
\hline R-squared & 0.411 & 0.197 & 0.414 & 0.204 & 0.414 & 0.203 & 0.414 & 0.203 \\
\hline Firm FE & YES & NO & YES & NO & YES & NO & YES & NO \\
\hline Country FE & NO & YES & NO & YES & NO & YES & NO & YES \\
\hline \multicolumn{4}{|l|}{ Panel B: Italy } & & & \multicolumn{3}{|c|}{ Panel C: Spain } \\
\hline & & \multicolumn{2}{|c|}{ (1) } & & & \multicolumn{3}{|c|}{ (1) } \\
\hline \multirow[t]{2}{*}{ 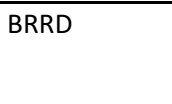 } & & \multicolumn{2}{|c|}{$-46.059 * * *$} & & & \multicolumn{3}{|c|}{ 466.782*** } \\
\hline & & & & & & & (2.502) & \\
\hline \multicolumn{2}{|l|}{ BRRD $x$ Treat } & \multicolumn{2}{|c|}{$15.572 * * *$} & & & \multicolumn{3}{|c|}{$-86.306^{* * *}$} \\
\hline & & \multicolumn{2}{|c|}{ (1.789) } & & & \multicolumn{3}{|c|}{$(2.986)$} \\
\hline \multirow[t]{2}{*}{ Crisis } & & \multicolumn{2}{|c|}{0.618} & & & \multicolumn{3}{|c|}{$152.628^{* * *}$} \\
\hline & & \multicolumn{2}{|c|}{ (1.660) } & & & \multicolumn{3}{|c|}{ (3.791) } \\
\hline \multirow[t]{2}{*}{ Constant } & & 118 & $7 * * *$ & & & & $93.277^{* * *}$ & \\
\hline & & & & & & & (1.119) & \\
\hline Obs. & & & & & & & 12,044 & \\
\hline R-squared & & & & & & & 0.545 & \\
\hline Firm FE & & & & & & & YES & \\
\hline
\end{tabular}

Description: The table reports the results for the preferred DiD estimation on peripheral euro area countries. Panel A includes all euro area peripheral economies. Panel B focuses on Italy, while Panel C considers Spain.

The dependent variable is the GAP variable (i.e. difference between sovereign CDS and non-sovereign CDS spreads) calculated on daily data and expressed in bps.

Firm and country fixed effects are included alternatively in the estimation on the whole sub-sample. For the analysis on the single countries, firm fixed effects are included. Robust standard errors, clustered at firm level, are reported in parentheses.

Note: The crisis dummy takes the value one from $1^{\text {st }}$ July 2011 to $1^{\text {st }}$ September 2012, zero otherwise.

${ }^{* * *}$ significant at the $1 \%$ level; $* *$ significant at the $5 \%$ level; * significant at the $10 \%$ level. 
Table 5 - The impact of BRRD on the sovereign-bank nexus: Large European countries

\begin{tabular}{|c|c|c|c|c|c|c|c|c|}
\hline \multicolumn{9}{|c|}{ Panel A: Preferred model specification - Large EU countries } \\
\hline & $(1)$ & $(2)$ & (3) & $(4)$ & $(5)$ & $(6)$ & (7) & $(8)$ \\
\hline BRRD & $\begin{array}{c}-14.885^{* *} \\
(7.041)\end{array}$ & $\begin{array}{c}-15.264 * * \\
(7.042)\end{array}$ & $\begin{array}{c}-14.891^{* *} \\
(7.041)\end{array}$ & $\begin{array}{c}-15.281^{* *} \\
(7.042)\end{array}$ & $\begin{array}{c}-14.899 * * \\
(7.042)\end{array}$ & $\begin{array}{c}-15.289 * * \\
(7.043)\end{array}$ & $\begin{array}{c}-14.916^{* *} \\
(7.044)\end{array}$ & $\begin{array}{c}-15.307^{* *} \\
(7.044)\end{array}$ \\
\hline BRRD $\times$ Treat & $\begin{array}{c}-25.582 * * \\
(10.415)\end{array}$ & $\begin{array}{c}-23.971 * * \\
(10.438)\end{array}$ & $\begin{array}{c}-25.639 * * \\
(10.422)\end{array}$ & $\begin{array}{c}-23.991 * * \\
(10.444)\end{array}$ & $\begin{array}{c}-25.637^{* *} \\
(10.422)\end{array}$ & $\begin{array}{c}-23.989 * * \\
(10.444)\end{array}$ & $\begin{array}{c}-25.639 * * \\
(10.422)\end{array}$ & $\begin{array}{c}-23.991^{* *} \\
(10.444)\end{array}$ \\
\hline Crisis & $\begin{array}{c}45.369^{* * *} \\
(6.944)\end{array}$ & $\begin{array}{c}50.771^{* * *} \\
(7.285)\end{array}$ & $\begin{array}{c}46.034^{* * *} \\
(6.975)\end{array}$ & $\begin{array}{c}51.799 * * * \\
(7.339)\end{array}$ & $\begin{array}{c}46.074^{* * *} \\
(6.979)\end{array}$ & $\begin{array}{c}51.842^{* * *} \\
(7.344)\end{array}$ & $\begin{array}{c}45.985^{* * *} \\
(6.972)\end{array}$ & $\begin{array}{c}51.748 * * * \\
(7.336)\end{array}$ \\
\hline Treat & & $\begin{array}{c}11.359 \\
(13.390)\end{array}$ & & $\begin{array}{c}11.223 \\
(13.400)\end{array}$ & & $\begin{array}{c}11.222 \\
(13.400)\end{array}$ & & $\begin{array}{c}11.223 \\
(13.400)\end{array}$ \\
\hline ITRAXX & & & $\begin{array}{c}-0.169 * * * \\
(0.028)\end{array}$ & $\begin{array}{c}-0.172^{* * *} \\
(0.028)\end{array}$ & & & & \\
\hline STOXX600 & & & & & $\begin{array}{c}0.635 * * * \\
(0.086)\end{array}$ & $\begin{array}{c}0.667^{* * *} \\
(0.090)\end{array}$ & & \\
\hline vSTOXX & & & & & & & $\begin{array}{c}-0.086^{* * *} \\
(0.010)\end{array}$ & $\begin{array}{c}-0.084^{* * *} \\
(0.010)\end{array}$ \\
\hline Constant & $\begin{array}{c}95.146^{* * *} \\
(2.352)\end{array}$ & $\begin{array}{c}91.100 * * * \\
(8.862)\end{array}$ & $\begin{array}{c}95.256^{* * *} \\
(2.352)\end{array}$ & $\begin{array}{c}91.200 * * * \\
(8.864)\end{array}$ & $\begin{array}{c}95.253^{* * *} \\
(2.352)\end{array}$ & $\begin{array}{c}91.197 * * * \\
(8.864)\end{array}$ & $\begin{array}{c}95.296^{* * *} \\
(2.354)\end{array}$ & $\begin{array}{c}91.240 * * * \\
(8.867)\end{array}$ \\
\hline Obs. & 307,250 & 307,250 & 306,700 & 306,700 & 306,700 & 306,700 & 306,700 & 306,700 \\
\hline R-squared & 0.662 & 0.064 & 0.662 & 0.065 & 0.662 & 0.065 & 0.662 & 0.065 \\
\hline Firm FE & YES & NO & YES & NO & YES & NO & YES & NO \\
\hline Country FE & NO & YES & NO & YES & NO & YES & NO & YES \\
\hline \multicolumn{9}{|c|}{ Panel B: Preferred model specification - Large euro area countries } \\
\hline & $(1)$ & $(2)$ & (3) & (4) & $(5)$ & $(6)$ & (7) & $(8)$ \\
\hline BRRD & $\begin{array}{c}-30.711^{* * *} \\
(11.653)\end{array}$ & $\begin{array}{c}-31.325^{* * *} \\
(11.662)\end{array}$ & $\begin{array}{c}-30.711^{* * *} \\
(11.651)\end{array}$ & $\begin{array}{c}-31.341^{* * *} \\
(11.661)\end{array}$ & $\begin{array}{c}-30.726^{* * *} \\
(11.652)\end{array}$ & $\begin{array}{c}-31.354 * * * \\
(11.662)\end{array}$ & $\begin{array}{c}-30.749^{* * *} \\
(11.655)\end{array}$ & $\begin{array}{c}-31.379 * * * \\
(11.664)\end{array}$ \\
\hline BRRD $\times$ Treat & $\begin{array}{c}-5.189 \\
(15.996)\end{array}$ & $\begin{array}{c}-3.611 \\
(16.058)\end{array}$ & $\begin{array}{c}-5.319 \\
(16.004)\end{array}$ & $\begin{array}{c}-3.746 \\
(16.067)\end{array}$ & $\begin{array}{c}-5.317 \\
(16.004)\end{array}$ & $\begin{array}{c}-3.744 \\
(16.068)\end{array}$ & $\begin{array}{c}-5.319 \\
(16.004)\end{array}$ & $\begin{array}{c}-3.746 \\
(16.067)\end{array}$ \\
\hline Crisis & $\begin{array}{c}59.770^{* * *} \\
(10.695)\end{array}$ & $\begin{array}{c}65.375 * * * \\
(11.272)\end{array}$ & $\begin{array}{c}60.710^{* * *} \\
(10.746)\end{array}$ & $\begin{array}{c}66.716 * * * \\
(11.361)\end{array}$ & $\begin{array}{c}60.758^{* * *} \\
(10.752)\end{array}$ & $\begin{array}{c}66.769 * * * \\
(11.368)\end{array}$ & $\begin{array}{c}60.636^{* * *} \\
(10.741)\end{array}$ & $\begin{array}{c}66.641^{* * *} \\
(11.356)\end{array}$ \\
\hline Treat & & $\begin{array}{c}11.834 \\
(19.775)\end{array}$ & & $\begin{array}{c}11.754 \\
(19.798)\end{array}$ & & $\begin{array}{c}11.752 \\
(19.799)\end{array}$ & & $\begin{array}{c}11.754 \\
(19.798)\end{array}$ \\
\hline ITRAXX & & & $\begin{array}{c}-0.251^{* * *} \\
(0.043)\end{array}$ & $\begin{array}{c}-0.251^{* * *} \\
(0.044)\end{array}$ & & & & \\
\hline STOXX600 & & & & & $\begin{array}{c}0.873 * * * \\
(0.132)\end{array}$ & $\begin{array}{c}0.906 * * * \\
(0.138)\end{array}$ & & \\
\hline VSTOXX & & & & & & & $\begin{array}{c}-0.118^{* * *} \\
(0.015)\end{array}$ & $\begin{array}{c}-0.114^{* * *} \\
(0.015)\end{array}$ \\
\hline Constant & $\begin{array}{c}104.137^{* * *} \\
(3.528)\end{array}$ & $\begin{array}{c}99.474 * * * \\
(12.908)\end{array}$ & $\begin{array}{c}104.295^{* * *} \\
(3.529)\end{array}$ & $\begin{array}{c}99.618 * * * \\
(12.913)\end{array}$ & $\begin{array}{c}104.294^{* * *} \\
(3.530)\end{array}$ & $\begin{array}{c}99.617^{* * *} \\
(12.913)\end{array}$ & $\begin{array}{c}104.353^{* * *} \\
(3.533)\end{array}$ & $\begin{array}{c}99.675^{* * *} \\
(12.918)\end{array}$ \\
\hline Obs. & 179,905 & 179,905 & 179,506 & 179,506 & 179,506 & 179,506 & 179,506 & 179,506 \\
\hline R-squared & 0.596 & 0.091 & 0.597 & 0.093 & 0.597 & 0.093 & 0.597 & 0.093 \\
\hline Firm FE & YES & NO & YES & NO & YES & NO & YES & NO \\
\hline Country FE & NO & YES & NO & YES & NO & YES & NO & YES \\
\hline
\end{tabular}


Table 5 - Continued

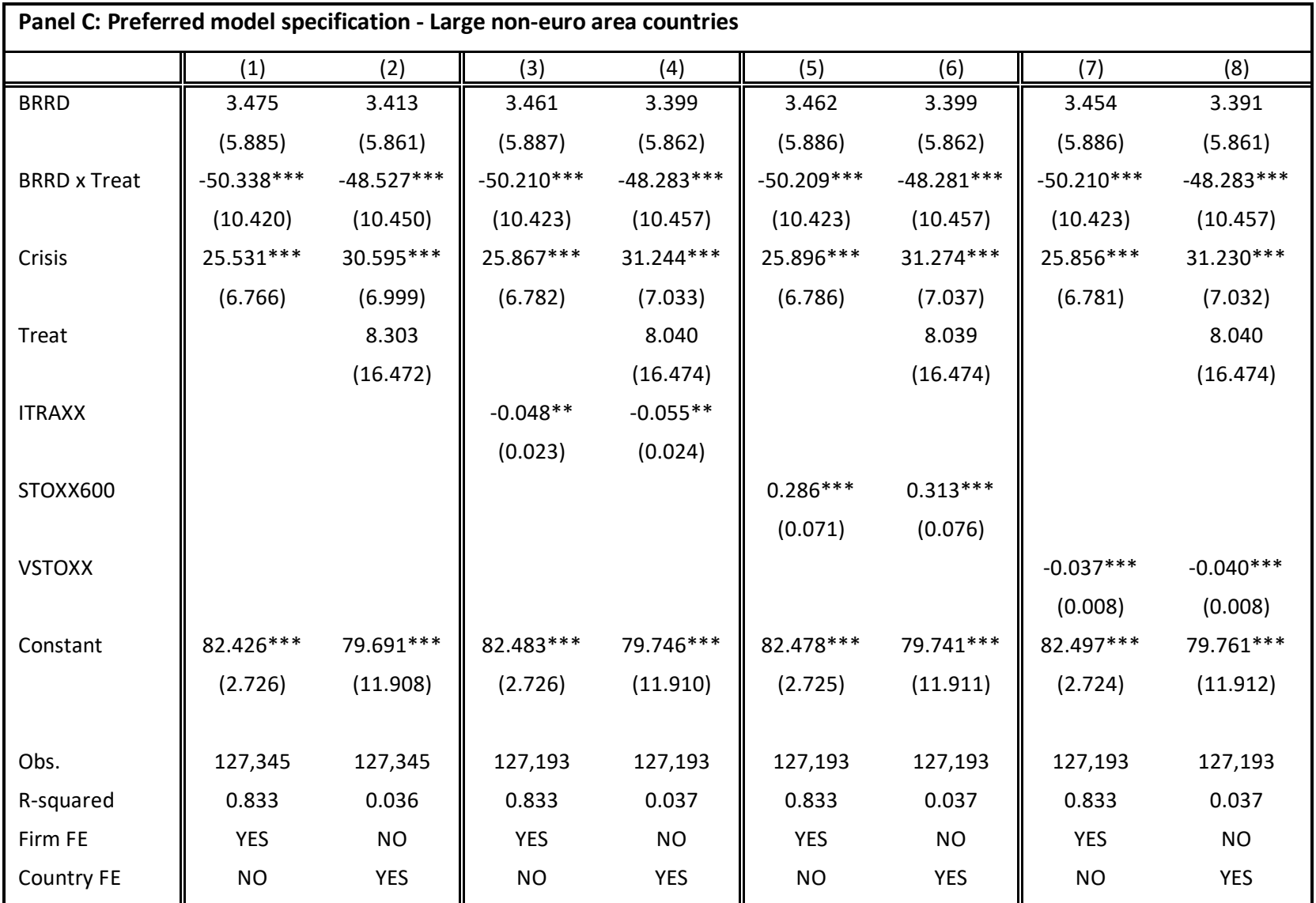

Description: The table reports the results for the preferred DiD estimation on large European countries. Panel A includes all large EU economies (i.e. France, Germany, Italy, Netherlands, Spain, Sweden and United Kingdom). Panel B focuses on large euro area countries (i.e. France, Germany, Italy, Netherlands and Spain), while Panel C considers large EU, noneuro area countries (i.e. Sweden and United Kingdom).

The dependent variable is the GAP variable (i.e. difference between sovereign CDS and non-sovereign CDS spreads) calculated on daily data and expressed in bps.

Firm and country fixed effects are included alternatively. Robust standard errors, clustered at firm level, are reported in parentheses.

Note: The crisis dummy takes the value one from $1^{\text {st }}$ July 2011 to $1^{\text {st }}$ September 2012, zero otherwise.

${ }^{* * *}$ significant at the $1 \%$ level; ${ }^{* *}$ significant at the $5 \%$ level; ${ }^{*}$ significant at the $10 \%$ level. 
Figure 1 - Sovereign and non-sovereign time series of CDS spreads

AUSTRIA

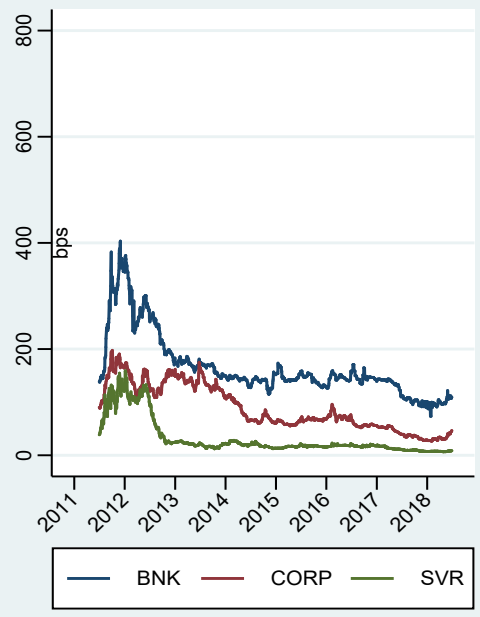

SPAIN

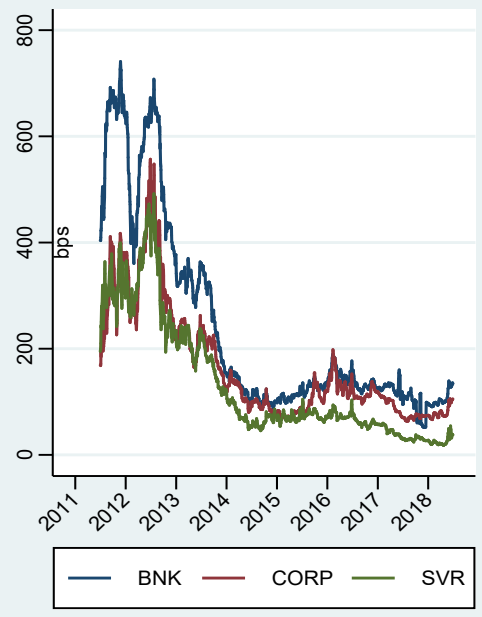

NETHERLANDS

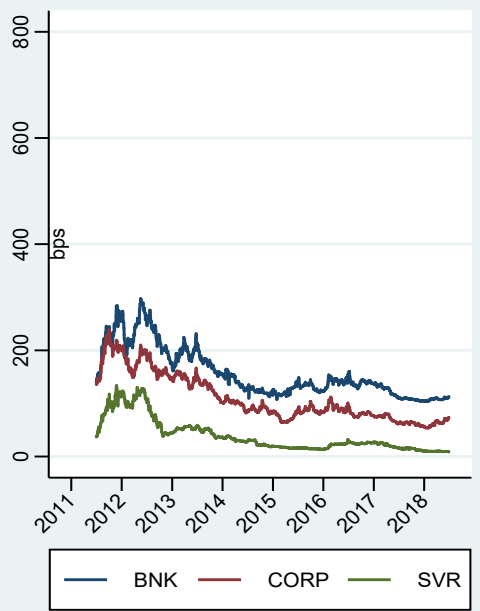

BELGIUM

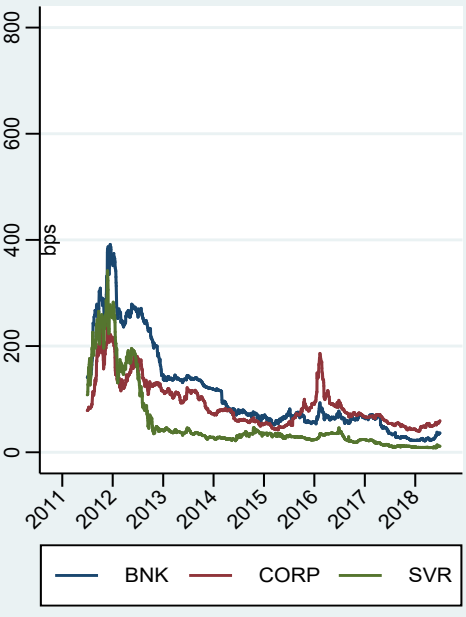

FRANCE

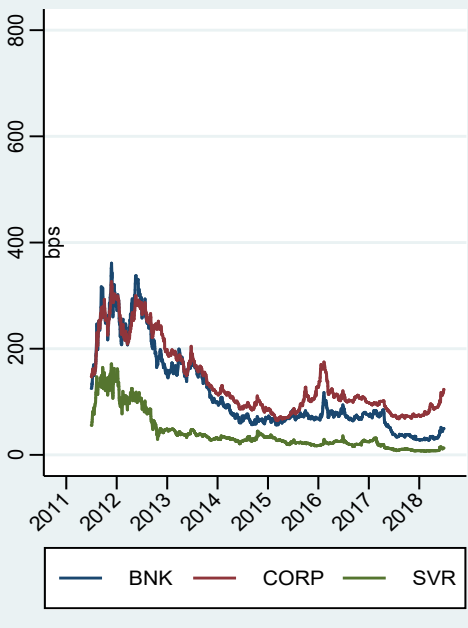

SWEDEN

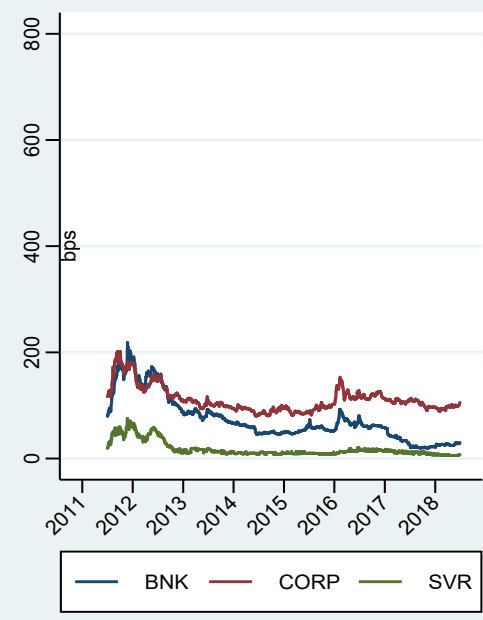

GERMANY

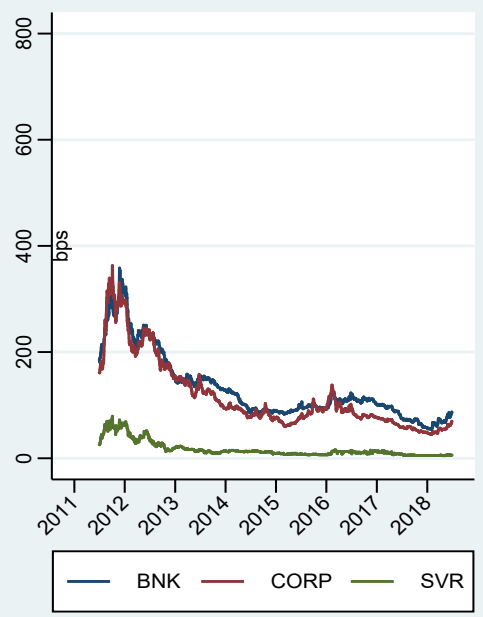

ITALY

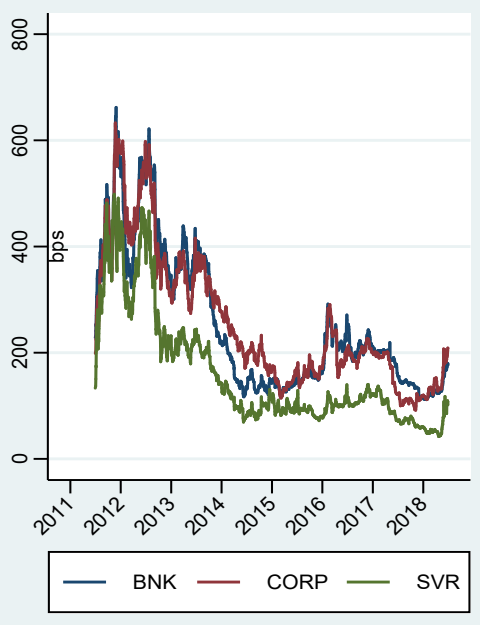

UNITED_KINGDOM

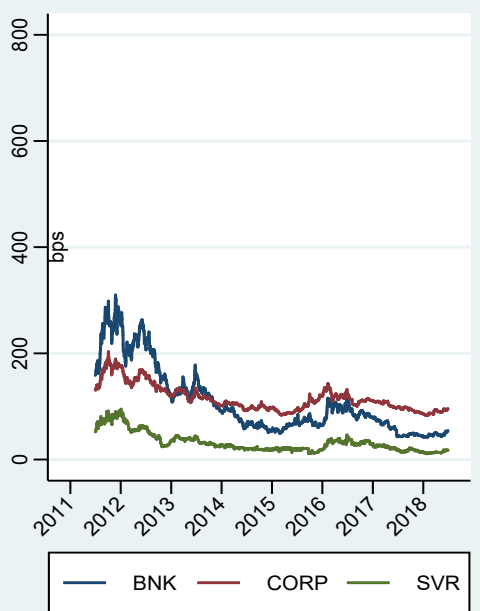

Description: The figure illustrates daily time series of CDS spreads for (i) sovereigns, (ii) banks and (iii) non-financial corporates (in bps) for nine selected EU countries.

Note: For comparability reasons, all the graphs have the same scaling on the vertical axis. 
Figure 2 - CDS trends (pre-treatment period)

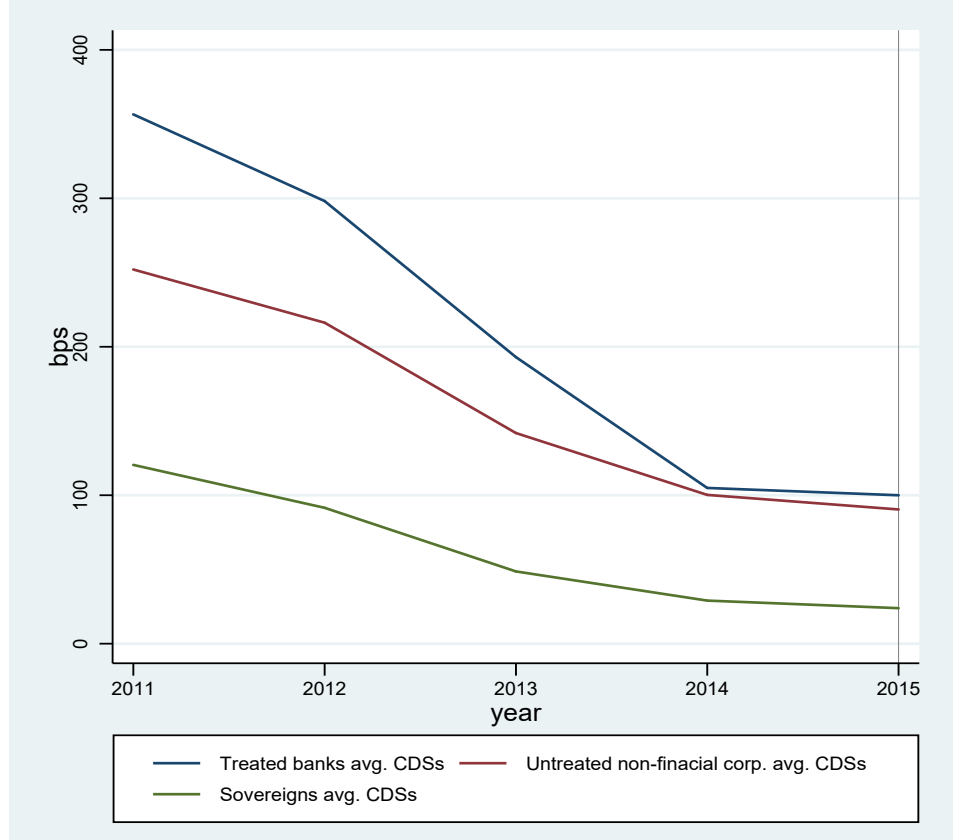

Description: The figure illustrates annual average CDS spreads (bps) for (i) treated firms, (ii) untreated firms and (iii) respective sovereigns in the pre-treatment period (i.e. from July 2011 to December 2014). 